\title{
Geosentetik Kil Örtü Hidrasyon Yönteminin Alt Zemin Koşullarına Bağlı Olarak Değerlendirilmesi
}

\author{
Tuğçe ÖZDAMAR KUL ${ }^{1}$ \\ Ali Hakan ÖREN ${ }^{2}$
}

$\ddot{O} \mathbf{z}$

Sunulan çalışma, geosentetik kil örtü (GKÖ) hidrasyonunda esnek duvarlı permametre hücrelerinin kullanıldığı iki yöntemi karşılaştırmaktadır. Çalışma kapsamında GKÖ’ler sıkıştırılmış siltli kum ve zeolit zeminler üzerine yerleştirilmiş ve zamana bağlı olarak alt zeminden su emme miktarları belirlenmiştir. Bu işlem literatürde GKÖ hidrasyonu olarak bilinmektedir. Bu çalışmada GKÖ’ler iki permametre hücresinin kullanıldığı kontrol örnekli yöntem (KÖY) ve daha büyük çaplı tek permametre hücresinin kullanıldığ 1 tek büyük örnekli yöntem (TBÖY) ile hidrate edilmiştir. Hidrasyon süreleri sonunda her iki yöntemle hidrate edilen GKÖ’lerin içindeki bentonitlerin su içerikleri karşılaştırılmıştır. Aynı hidrasyon süreleri için her iki yöntemden elde edilen nihai bentonit su içerikleri arasındaki fark, alt zemin tabakasının siltli kum ve zeolit olmasına göre sırasıyla azami \%8 ve \%20 olarak belirlenmiştir. Ayrıca kullanılan hidrasyon yönteminden bağımsız olarak zeolit üzerinde hidrate edilen GKÖ’nün bentonit su içeriği siltli kum üzerinde hidrate edilenden iki kat fazla bulgulanmıştır ( $125 \%$ ve $65 \%)$. Hidrasyon sonunda alt zeminlerin su içeriği profilleri (alt zemin yüksekliği boyunca) karşılaştırıldığında siltli kum ve zeolitin benzer davranış gösterdiği görülmüştür. KÖY ve TBÖY ile hidrate edilen GKÖ’lerin nihai hidrolik iletkenlikleri hemen hemen aynı elde edilmiş olmasına rağmen, hidrolik davranışlar birbirinden farklıdır. Bu farklılık, GKÖ'lerin hidrolik iletkenlik deneyleri sırasında bünyelerine su almaya devam etmiş olmalarından kaynaklanmıştır. Diğer yanda, KÖY ile şişmiş bentonit partiküllerinin durumu daha iyi görüntülenebilmiş, fakat iki adet permametre ve sıkıştırılmış alt zemin kullanılması gerektiğinden bu yöntemin TBÖY'e kıyasla daha pahalı ve zahmetli olduğu görülmüştür.

Anahtar Kelimeler: Atık depolama alanı, bentonit, geosentetik kil örtü, hidrasyon, hidrolik iletkenlik, üst örtü.

\footnotetext{
Not: Bu yazı

- Yayın Kurulu'na 29.03.2016 günü ulaşmıştır. 18.04.2017 günü yayımlanmak üzere kabul edilmiştir.

- 31 Temmuz 2018 gününe kadar tartışmaya açıktır.

- DOI: $10.18400 /$ tekderg. 378245
}

1 Dokuz Eylül Üniversitesi, Fen Bilimleri Enstitüsü, İzmir - tugce.ozdamar@deu.edu.tr

2 Dokuz Eylül Üniversitesi, İnşaat Mühendisliği Bölümü, İzmir - ali.oren@deu.edu.tr 


\section{ABSTRACT \\ Evaluation of the Hydration Method of Geosynthetic Clay Liners in View of Subsoil Conditions}

Presented study compares two hydration methods for geosynthetic clay liners (GCL) which were conducted through flexible-wall permeameters. In this study, GCLs were hydrated over silty sand and zeolite subsoils. At the end of the hydration durations, bentonite water contents from the control sample method (CSM) that uses two permeameters and the single large sample method (SLSM) that uses one permeameter were compared. There are $8 \%$ and $20 \%$ differences between the final bentonite water contents obtained from two methods when silty sand and zeolite were used as subsoil, respectively. Regardless of the hydration method used, bentonite water content of GCL hydrated over zeolite was two times greater than that of GCL hydrated over silty sand $(\sim 125 \%$ and $65 \%)$. In addition, subsoil water content profiles along silty sand and zeolite were quite similar. Although the final hydraulic conductivities of the GCLs hydrated with CSM and SLSM were almost the same, the hydraulic behaviors were different. This difference was caused by the water uptake of GCLs during the hydraulic conductivity tests. In contrast, although swelling of bentonite particles can be monitored more easily in CSM, this method is more expensive and troublesome than SLSM as it requires two parameameters and compacted specimens.

Keywords: Waste disposal area, bentonite, geosynthetic clay liner, hydration, hydraulic conductivity, cover.

\section{GíRiş}

Geosentetik Kil Örtüler (GKÖ’ler) sahip oldukları düşük hidrolik iletkenlik özelliği ve arazide kolay uygulanabilirliği ile katı atık depolama alanları, gölet tabanları, kanal yatakları ve çeşitli maden işletmelerinin atık havuzları dahil pek çok alanda yaygın olarak kullanılmaktadır $[1,2]$.

GKÖ’ler iki geotekstil arasına bentonit serilmek sureti ile imal edilen ince kompozit malzemelerdir. İçindeki bentonitin mineralojisi ile fiziksel ve kimyasal özellikleri GKÖ’lerin geçirimsizliğini önemli ölçüde etkilemektedir. Literatürde, sodyumca zengin GKÖ’lerin su ile süzdürüldüğü durumdaki hidrolik iletkenliklerinin yaklaşık $2.0 \times 10^{-9} \mathrm{~cm} / \mathrm{s}$ olduğu rapor edilmiştir $[3,4,5,6,7,8]$.

$\mathrm{Bu}$ özelliklerin yanı sıra GKÖ içindeki bentonitin sahip olduğu su içeriği değeri de geçirgenlik üzerinde belirleyici rol oynamaktadır. Önceki çalışmalarda GKÖ su içeriğinin artmasının hidrolik iletkenlik üzerinde azaltıcı etkisi olduğu raporlanmıştır [9, 10]. Benzer şekilde, Benson vd. [11] arazide kullanımda olan GKÖ’lerden aldıkları örnekler üzerinde yaptıkları çalışmada en düşük hidrolik iletkenlik değerinin GKÖ su içeriğinin yüksek olduğu durumda (\%59 - \%67) elde edildiğini raporlamışlardır.

GKÖ’lerin su içerikleri, arazide üzerine yerleştirildikleri zemin tabakalarından bünyelerine çektikleri su miktarı ile ilişkilidir. Özellikle atık depolama alanlarında üst örtü teşkili farklı tipte zemin malzemeleri ile değişik kalınlıklarda yapılabilmektedir (Şekil 1). Genel olarak bakıldığında üst örtü tabakasında GKÖ üzerine oldukça küçük efektif gerilmelerin etki ettiği görülmektedir (10 25 kPa). Düşük efektif gerilme altında geçirimsiz kabul edilen GKÖ’nün 
hidrolik iletkenliği de daha yüksek olmaktadır $[12,13]$. Bu nedenle GKÖ’nün alt zemin tabakasından emme yoluyla su içeriğini arttırarak şişmesi, düşük hidrolik iletkenliğin uzun süreli muhafaza edilebilmesi için oldukça önemlidir.

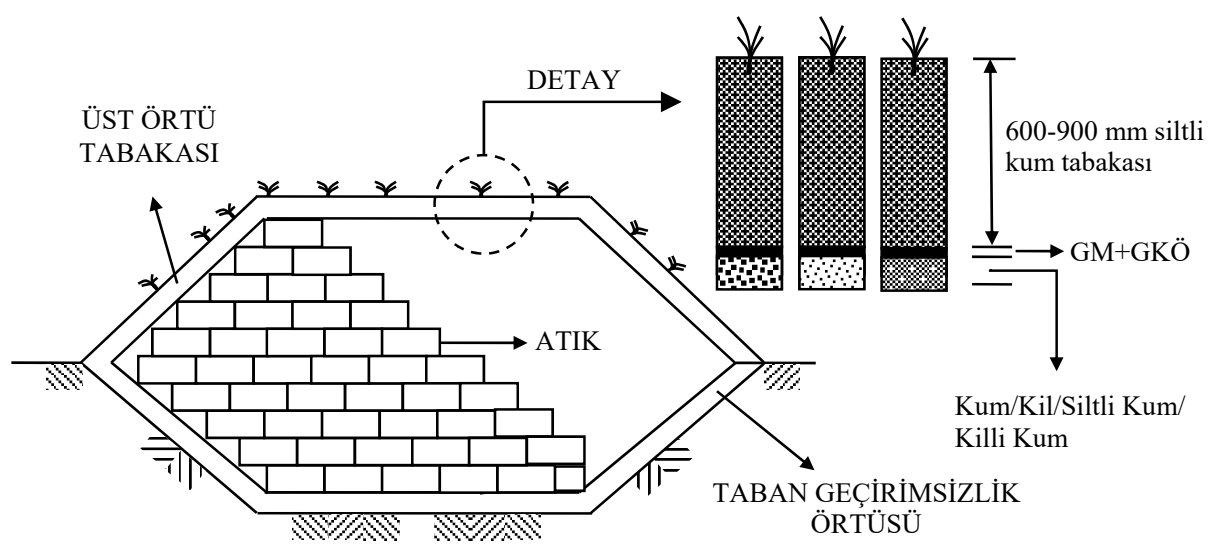

Şekil 1. Atık depolama alanı bileşenlerinin basit gösterimi ve üst örtü tabakası detayl.

GKÖ içindeki bentonitin alt zeminden su çekmesi genellikle "hidrasyon" olarak adlandırılmaktadır. Son dönemde GKÖ hidrasyonu ile ilgili yapılan çalışmaların sayısı artmıştır. Bu konu literatürde iki şekilde ele alınarak incelenmiştir. Çalışmalardan önemli bir kısmı yalnızca GKÖ hidrasyonunu ele almış ve hidrasyonu etkileyen parametreleri incelemiş̧ir [14-18]. Görece daha sınırlı sayıdaki çalışmalarda ise GKÖ hidrasyonu ve hidrolik iletkenlik birlikte ele alınarak araştırılmıştır $[19,20]$.

GKÖ hidrasyonu üzerine yapılan laboratuvar çalışmalarında arazi koşullarının daha iyi temsil edilebilmesi için GKÖ’ler sıkıştırılmış zeminler üzerinde belirli süreler boyunca hidrate edilmişlerdir. Bu çalışmalarda genellikle iki farklı deney sistemi kullanılmıştır: i) PVC (ve/veya akrilik) kalıpların kullanıldığı sistemler ve ii) esnek duvarlı permametrelerin kullanıldığı kontrol örnekli sistemler.

GKÖ hidrasyonunun PVC kalıplarda gerçekleştirildiği deneylerde istenilen boyutlarda örneklerin hazırlanması mümkün hale gelebilmektedir. Örnek boyutlarının büyütülmesiyle arazi koşulları daha iyi temsil edilebilmektedir. Bu şekilde hazırlanan numunelerin merkezinden hidrolik iletkenlik deneylerinde kullanmak üzere örnekler çıkarılabilmekte ve kalan kısımdan bentonitin hidrasyon sonundaki su içeriği ve diğer bazı fiziko-kimyasal özellikleri belirlenebilmektedir. Dolayısıyla su içeriği (veya diğer parametreler) ile hidrolik iletkenlik ilişkisi daha gerçekçi olarak karşılaştırılabilmektedir.

Literatürde farklı ebatlarda PVC kalıpların kullanıldığı çalışmalara sık rastlanmaktadır. Rayhani vd. [14] $15 \mathrm{~cm}$ çapında ve $50 \mathrm{~cm}$ yüksekliğinde; Anderson vd. [15], Sarabian ve Rayhani [16] ve Barclay ve Rayhani [17] $15 \mathrm{~cm}$ çapında ve $30 \mathrm{~cm}$ yüksekliğinde; Chevrier vd. [18] $9.5 \mathrm{~cm}$ çapında ve $30 \mathrm{~cm}$ yüksekliğindeki PVC kalıplar içerisinde hazırladıkları farklı tipteki zeminler üzerinde GKÖ’lerin sadece hidrasyon davranışını incelemişlerdir. 
Bununla birlikte Katsumi vd. [19] ise $10 \mathrm{~cm}$ çapında $15 \mathrm{~cm}$ yüksekliğindeki akrilik hücre içerisinde iki farklı GKÖ hidrate etmişlerdir. Hidrasyon sonunda GKÖ’lerin ortasından hidrolik iletkenlik deneylerinde kullanmak üzere $6 \mathrm{~cm}$ çapında örnekler almışlardır. GKÖ hidrasyonunun PVC kalıplar içerisinde gerçekleştirildiği uygulamalardan sadece bu çalışmada GKÖ hidrasyonu ile hidrolik iletkenlik ilişkisi irdelenmiştir. Ancak PVC kalıpların kullanıldığı diğer çalışmalarda da olduğu gibi bu çalışmada da uygulanan gerilme sınırlı kalmıştır (1-2 kPa). Zira bu yöntemde nispeten yüksek gerilmelerin uygulanması oldukça zordur. Mesela, $15 \mathrm{~cm}$ çapa sahip bir örnek üzerine $1 \mathrm{kPa}$ 'lı gerilme uygulamak için $1.8 \mathrm{~kg}$ gerekirken, örnek çapı 60 cm'ye çıkarıldığında bu yük 28 kg'a çıkmaktadır. Diğer yanda ise arazi durumunu temsilen gerilme arttırılmak istenirse, yine yüksek miktarda yük uygulanması gerekmektedir (10 kPa gerilme için $15 \mathrm{~cm}$ ve $60 \mathrm{~cm}$ çaplı örnekler için sırasıyla $18 \mathrm{~kg}$ ve $280 \mathrm{~kg}$ yük uygulamak gerekmektedir). Bu da laboratuvar ortamında yürütülen çalışmayı zorlaştırmaktadır.

Esnek duvarlı permametrelerin kullanıldığı ikinci deney sisteminde ise deneyler kontrol örnekleri hazırlanarak yürütülmektedir. Bu amaçla iki adet aynı çapta örnek (bu genelde 10 cm olmaktadır) GKÖ rulosundan kesilerek biri hidrolik iletkenlik deneyinde, diğeri ise hidrasyon sonu GKÖ su içeriğinin belirlenmesinde kullanılmak üzere alt zemin tabakaları üzerinde aynı anda hidrate edilmektedir. Bu yöntemde sistem basınç paneline bağlandığı için hidrasyon sırasında örneklere uygulanmak istenen yükleme koşulları laboratuvarda rahatlıkla temsil edilebilmektedir. Fakat bu yöntemin kullanıldığı çalışma sayısı literatürde oldukça azdır. Bradshaw vd. [20] bu yöntemle $10 \mathrm{kPa}$ gerilme altında hidrate ettikleri GKÖ örneklerinin hidrolik iletkenlik davranışlarını incelemişlerdir.

Kontrol örnekli yöntem (KÖY) olarak adlandırılabilecek bu sistem ile yapılan deneylerde hidrasyonda kullanılan sıkıştırılmış zemin tabakalarının hedeflenen su içeriği ve kuru birim hacim ağırlık değerlerinden saptığ 1 ve/veya bu zeminler üzerinde hidrate edilen GKÖ'lerin fiziksel özelliklerinin (birim alana gelen bentonit miktarlarının) farklı olduğu durumlarda su içeriği ile hidrolik iletkenlik deney sonuçlarının yorumlanması güçleşebilir. Diğer yanda ise bu sistemde aynı anda iki esnek duvarlı permametre hücresi kullanıldığından yöntem pratik olmaktan uzaklaşmaktadır. Bu durum ancak Katsumi vd.'nin [19] PVC kalıbı kullanarak yaptığı GKÖ hidrasyonu uygulamasının esnek duvarlı permametre sistemine adapte edilmesi ile ortadan kaldırılabilir. Kullanılacak yeni sistem ile daha büyük çaplı $(15 \mathrm{~cm})$ GKÖ’ler istenen gerilmeler altında esnek duvarlı permametre hücrelerinde hidrate edilebilir ve aynı örnek içerisinden hem su içeriği için hem de hidrolik iletkenlik deneyleri için numune alınması mümkün olabilir. Böylece sonuçların yorumlanmasının daha gerçekçi olması beklenmelidir.

Literatürdeki çalışmalarda GKÖ’lerin hidrasyonuna etki eden faktörlerden bazıları (alt zemin tabakası tipi, hidrasyon süresi ve ortam sıcaklığı) araştırılmıştır. Ancak hidrasyon sırasında hangi yöntemin kullanılabileceği konusunda bir araştırma bu zamana kadar yapılmamıştır. Burada sunulan çalışmada arazi yükleme koşullarının daha iyi yansıtılabilmesi için GKÖ hidrasyonları esnek duvarlı permametre hücreleri içerisinde iki farklı yöntem kullanılarak gerçekleştirilmiştir: i) iki permametre hücresinin kullanıldığı kontrol örnekli yöntem (KÖY) [20] ve ii) Katsumi vd.'den [19] modifiye edilen, fakat PVC kalıplar yerine permametre hücrelerinin kullanıldığ 1 tek büyük örnekli yöntem (TBÖY). Kullanılan yönteme bağlı olarak hidrasyon sonuçları farklı görüntü oranına sahip alt zemin tabakaları ile birlikte değerlendirilmiştir (alt zemin tabakası görüntü oranı: sıkıştırılmış örnek boyunun (L), çapa 
(D) bölünmesi, L/D). Ayrıca çalışma kapsamında kullanılan alt zemin tabakası tipinin (siltli kum ve zeolit) GKÖ hidrasyonuna etkisi de deney programına dahil edilmiştir. Hidrasyon sonrasinda ise GKÖ'lerden bir kısmı esnek duvarlı permametrelerle hidrolik iletkenlik deneyine tabi tutulmuştur.

\section{MALZEME VE YÖNTEM}

\subsection{Malzemeler}

Sunulan çalışmada GKÖ’lerin hidrasyonu için alt zemin malzemesi olarak Aydın katı atık depolama sahası içinden alınmış doğal zemin ile Rota Madencilik A.Ş.'den temin edilen zeolit kullanılmıştır. Birleştirilmiş Zemin Sınıflandırması'na (USCS) göre doğal zemin malzemesi ve zeolit siltli kum (SM) olarak sınıflandırılmıștır. ASTM D 698-07'ye [21] göre Standart Proctor enerjisi altında siltli kumun optimum su içeriği \%12, maksimum kuru birim hacim ağırlı̆̆ $18.3 \mathrm{kN} / \mathrm{m}^{3}$; zeolitin optimum su içeriği \% 46 , maksimum kuru birim hacim ağırlığı ise $10.5 \mathrm{kN} / \mathrm{m}^{3}$ olarak belirlenmiştir. Hidrasyon için kullanılacak GKÖ, rulo halinde yerli bir firmadan temin edilmiş olup içindeki bentonitin başlangıç su içeriği \% 12.6 'dır. GKÖ içinden çıkarılan bentonitin likit limiti Casagrande deney aleti ile \%108 olarak belirlenmiştir.

Alt zemin tabakaları paslanmaz çelikten imal edilen kalıplar içinde sıkıştırılmıştır. Sıkıştırma deneylerinde $10.2 \mathrm{~cm}$ ile $15.2 \mathrm{~cm}$ arasında değişen çaplara ve $11.6 \mathrm{~cm}$ ile $17.4 \mathrm{~cm}$ arasında boylara sahip kalıplar kullanılmıştır.

GKÖ hidrasyonları $10 \mathrm{~cm}$ ve $15 \mathrm{~cm}$ çapındaki esnek duvarlı permametre hücreleri içerisinde gerçekleştirilmiştir (Şekil 2a-b). Şekil 1'de gösterilen katı atık depolama alanı üst örtüsü üzerine gelebilecek yükü temsilen GKÖ’ler permametreler içerisinde $10 \mathrm{kPa}{ }^{\prime} l 1 \mathrm{k}$ hücre basınçları altında hidrate edilmişlerdir. Bu gerilme laboratuvarda askıda tutulan cam büretlere (borulara) $1 \mathrm{~m}$ yüksekliğinde su doldurmak sureti ile sağlanmıştır. Su yüksekliği hidrasyon süresi boyunca sürekli takip edilmiş, buharlaşma dolayısıyla cam boruda su seviyesi azaldığında eksilen kısım hemen tamamlanmıştır.

Hidrolik iletkenlik deneylerinde de aynı esnek duvarlı permametre hücreleri kullanılmıştır. Permametre sistemi ve kullanılan esnek duvarlı hücrelerle ilgili gerekli bilgi Ören ve Demirkıran'da [22] detaylı olarak verilmiştir.

GKÖ'ler rulolardan kesilirken ve hidrolik iletkenlik deneyleri safhasında süzdürme sıvısı olarak deiyonize su (damıtık su) kullanılmıştır. Deiyonize su, Sartorius Arium Comfort Kombine su saflaştırma sisteminden elde edilmiş̧ir. Sıkıştırma öncesinde alt zeminlerin (siltli kum ve zeolit) 1slatılmasında ve permametre hücrelerine basınç sağlayan cam borularda ise İzmir şebeke suyu kullanılmıştır.

Atık depolama sahası üst örtüsünün laboratuarda tam olarak temsil edilebilmesi için sıkıştırılmış alt zemin tabakası üzerine GKÖ yerleştirilmiştir. GKÖ'nün üzerine Drefon S1000 tipi kalın ve örgüsüz geotekstil, onun üzerine de her iki yüzü pürüzsüz HDPE geomembran konduktan sonra hidrasyon işlemine geçilmiştir. Kullanılan bu geosentetik malzemeler, Dokuz Eylül Üniversitesi Zemin Mekaniği Laboratuarı'nda bulunan rulolardan kesilerek kullanılmıştır. 

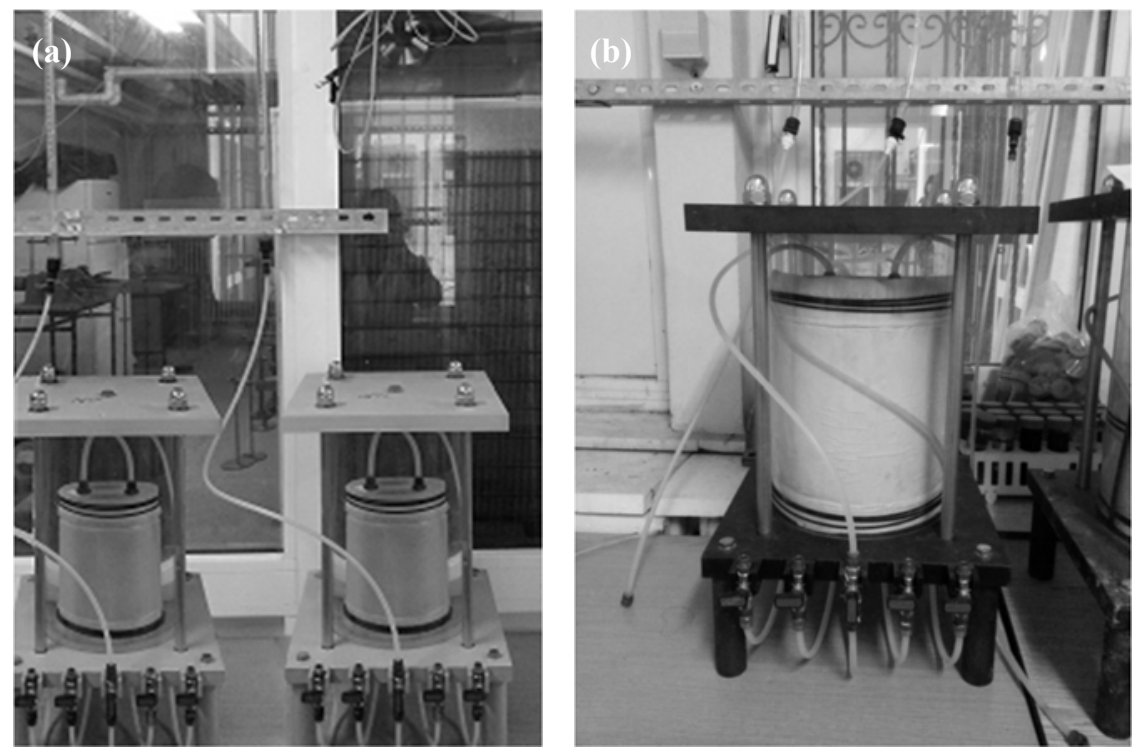

Şekil 2. Hidrasyon için kullanılan permametre sistemlerinin genel görünümü: a) $10 \mathrm{~cm}$ çaplı permametrelerin kullanıldığı kontrol örnekli yöntem (KÖY) ve b) $15 \mathrm{~cm}$ çaplı permametrelerin kullanıldiğı tek büyük örnekli yöntem (TBÖY)

\subsection{Yöntemler}

\subsubsection{Alt Zemin Tabakalarının Stkıştırılması}

Siltli kum ve zeolit, optimum su içeriğinin $\% 2$ sslak kısmında (siltli kum için $\mathrm{w}=\% 14$; zeolit için $\mathrm{w}=\% 48$ ) hazırlanmıştır. Doğal neminde olan numunelere plastik leğenlerde püskürteç ile yavaş yavaş su ilave ederek hedeflenen bu su içeriği değerlerine ulaşılmıştır. Islatma sırasında numuneler sürekli karıştııılmış, sonrasında suyun her tarafa homojen dağıllabilmesi için sslak numuneler 24 saat süre ile plastik poşetler içerisinde bekletilmişlerdir. Bekleme süresi sonunda numuneler tekrar plastik leğenlere boşaltılarak son kez karıştırılmışlar, daha sonra da Çizelge 1'de verilen görüntü oranlarında otomatik kompaktör kullanılarak Standart Proctor enerjisi ile sıkıştııılmışlardır. Görüntü oranına bağlı olarak örneklerin Standart Proctor enerjisi altında aynı kuru birim hacim ağırlık değerlerinde $\left(\gamma_{\mathrm{d}} \approx 18.1 \mathrm{kN} / \mathrm{m}^{3} ; \gamma_{\mathrm{d}} \approx 10.3\right.$ $\mathrm{kN} / \mathrm{m}^{3}$ ) sıkıştırılabilmeleri için tabaka sayısı ve her tabakaya uygulanacak darbe adedi yeniden ayarlanmıştır (Çizelge 1).

Sıkıştırılan tabakalar arasında yeterli aderansın sağlanabilmesi için her tabaka üzerine ince uçlu spatula yardımıyla çizikler atılmış, daha sonra takip eden tabaka yerleştirilip sıkıştırılmıştır. Sıkıştırılan numune yüzeyi metal düzleştirici ile traşlandıktan sonra GKÖ'ye temas edecek en üstteki tabaka yüzeyi tekrar spatula ile çizikler atılarak pürüzlendirilmiştir. Sıkıştırılan numuneler hidrolik kriko ile metal kalıplarından dikkatli bir şekilde çıkarılarak permametre hücresine nakledilmiştir. 
Çizelge 1. GKÖ altına yerleştirilen alt zemin tabakası boyutları, sıkış̧trmada uygulanan tabaka saylst ve her tabakaya uygulanan darbe adedi

\begin{tabular}{cccccc}
\hline $\begin{array}{c}\text { Örnek } \\
\begin{array}{c}\text { Hazırlama } \\
\text { Yöntemi }\end{array}\end{array}$ & $\begin{array}{c}\text { Alt Zemin } \\
\text { Görüntü Oranı } \\
\text { GO=L/D }\end{array}$ & $\begin{array}{c}\text { Örnek Çapı } \\
\mathrm{D}(\mathrm{cm})\end{array}$ & $\begin{array}{c}\text { Örnek Boyu } \\
\text { L }(\mathrm{cm})\end{array}$ & $\begin{array}{c}\text { Tabaka } \\
\text { Sayıs }\end{array}$ & $\begin{array}{c}\text { Darbe / } \\
\text { Tabaka }\end{array}$ \\
\hline KÖY & 1.14 & 10.2 & 11.6 & 3 & 25 \\
TBÖY & 1.14 & 15.2 & 17.4 & 5 & 52 \\
TBÖY & 0.76 & 15.2 & 11.6 & 3 & 56 \\
\hline
\end{tabular}

\subsubsection{Hidrasyon için GKÖ örneklerinin hazırlanmast}

KÖY yönteminde birisi su içeriğinin belirlenmesinde, diğeri ise hidrolik iletkenlik deneyinde kullanılmak üzere her bir hidrasyon (kür) süresi için ikişer adet örnek hazırlanmıştır. Bunun için GKÖ rulosundan $20 \mathrm{~cm} \times 20 \mathrm{~cm}$ 'lik iki adet kare numune kesilmiş ve bunların ortasına kalemle $10 \mathrm{~cm}$ çapında daireler çizilmiştir. Bentonit kaybının önlenmesi amacıyla kalemle işaretlenen kesilme yüzeyleri deiyonize (damıtık) su ile az miktarda sslatılmışıtır. Bir süre ıslak bentonitin şişmesi beklenmiş ve daha sonra keskin uçlu maket bıçağı yardımıyla dairesel GKÖ, karesel parçadan çıkarılmıştır.

GKÖ'ler daha sonra hidrate edilmek üzere esnek duvarlı permametre hücrelerinin içine yerleştirilmiştir. Hidrasyon işleminde katı atık depolama sahasında üst örtü teşkili resmedilmiştir. Bunun için alt başlığın üzerine sırası ile Drefon S-1000 örgüsüz geotekstil, sıkıştırılmış alt zemin (siltli kum veya zeolit), GKÖ, HDPE geomembran, Drefon S-1000 geotekstil ve üst başlık yerleştirilmiştir (Şekil 3a). Tüm bu sistemin üzerinde lateks membran geçirildikten sonra alt ve üst başlığa üçer adet O-halka takılmış ve üst başlık hortum bağlantıları yapılmıştır (Şekil 3b). Permametre hücreleri su ile doldurulmuş (Şekil 3c) ve sistem üzerine $10 \mathrm{kPa}$ 'lık hücre basıncı uygulanmıştır (Şekil 3d). GKÖ hidrasyonunun yalnızca alt zemin tabakasından su çekilerek (emilerek) sağlanabilmesi için permametre hücrelerinin giriş ve çıkış vanaları hidrasyon süresi boyunca kapalı tutulmuştur.

İkinci yöntemde (TBÖY) ise GKÖ rulosundan kesilen $30 \mathrm{~cm} \times 30 \mathrm{~cm}$ 'lik kare numunenin ortasından bir adet $15 \mathrm{~cm}$ çapında dairesel örnek kesilmiştir. Alt zemin tabakası olarak kullanılan siltli kum veya zeolit, $15 \mathrm{~cm}$ çapındaki kalıpta sıkıştırılmış, sıkıştırılan örnek daha büyük çaptaki alt ve üst başlıklara sahip $(15 \mathrm{~cm})$ esnek duvarlı permametre hücresine nakledilmiştir. GKÖ’nün sıkıştırılmış örnek üzerine yerleştirilmesi ve onun üzerine de diğer geosentetik malzemelerin konulması sırası ile deney esnasında uygulanan diğer aşamalar KÖY ile aynıdır.

Çalışma kapsamında GKÖ hidrasyonları için KÖY ile 10 adet, TBÖY ile 6 adet olmak üzere toplam 16 adet örnek hazırlanmıştır. Alt zemin olarak siltli kumun kullanıldığı durumda kısa ve uzun dönem hidrasyon sürelerini temsilen 7 ve 62 günlük kür süreleri tatbik edilmiştir. GKÖ'ler sıkıştırılmış zeolitler üzerine yerleştirildiğinde ise esnek duvarlı permametrelerin etkin kullanılabilmesi için yapılan program dahilinde ancak 17 ve 30 günlük hidrasyon süreleri uygulanabilmiştir. 

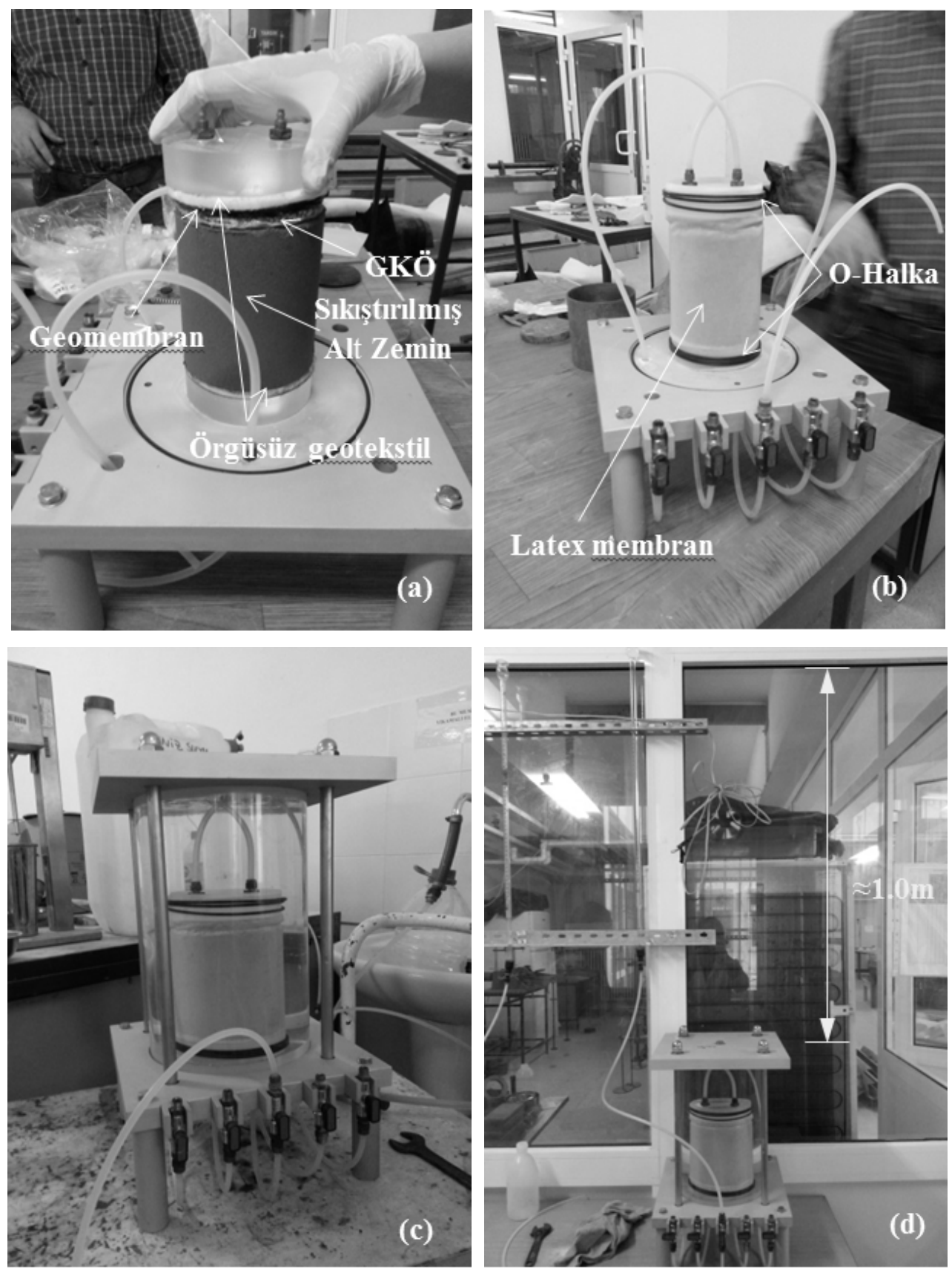

Şekil 3. Hidrasyon için GKÖ örneklerinin hazırlanması: a) GKÖ'nün alt zemin tabakası üzerine yerleştirilmesi, b) lateks membran ve O-halka geçirilmesi, c) hücreye su doldurulması, d) hücre basincinın uygulanması 


\subsubsection{Hidrasyon Sonrası GKÖ’lerin ve Alt Zemin Tabakalarının Su İçeriklerinin Belirlenmesi}

Hidrasyon sonunda hücre suyu boşaltılan permametrenin islak kısımları (özellikle lateks membran üzeri ve üst başlık) kağıt havlu ile kurulanmış, lateks membran dışarıya doğru sıyrılarak GKÖ ve alt zemine dışarıdan su girişi engellenmiştir. Daha sonra GKÖ ve sıkıştırılmış alt zemin permametre hücresinden çıkarılmıştır.

KÖY ile hidrate edilen GKÖ’lerden biri su içeriğini belirlemek üzere açılmıştır. Bunun için iğneleme yoluyla birbirine bağlanan örgülü ve örgüsüz geotekstillerin lifleri keskin uçlu maket bıçağı ile kesilmiştir. Kesim sırasında ekstra özen gösterilerek geotekstiller arasında kalan şişmiş bentonit tabakasının zarar görmesi engellenmeye çalışılmışırı. Bentonit tabakasının mevcut durumu görüntülendikten sonra tamamı su içeriğinin belirlenmesi için $105^{\circ} \mathrm{C}$ 'deki etüvde kurutulmuştur.

TBÖY'de ise hidrate olmuş GKÖ örneklerinin ortasından hidrolik iletkenlik deneylerinde kullanmak üzere $10 \mathrm{~cm}$ çapında ikincil örnekler çıkarılmıştır (Şekil 4). Hidrasyon sonu su içeriğinin belirlenebilmesi için GKÖ'nün kalan kısmındaki geotekstiller KÖY'dekine benzer şekilde ayrılarak bentonit tabakası açığa çıkarılmıştır. Bir spatula ile açığa çıkarılan bentonit siyrilarak kaba konmuş ve $105^{\circ} \mathrm{C}$ sicaklıktaki etüvde kurutulmuştur.

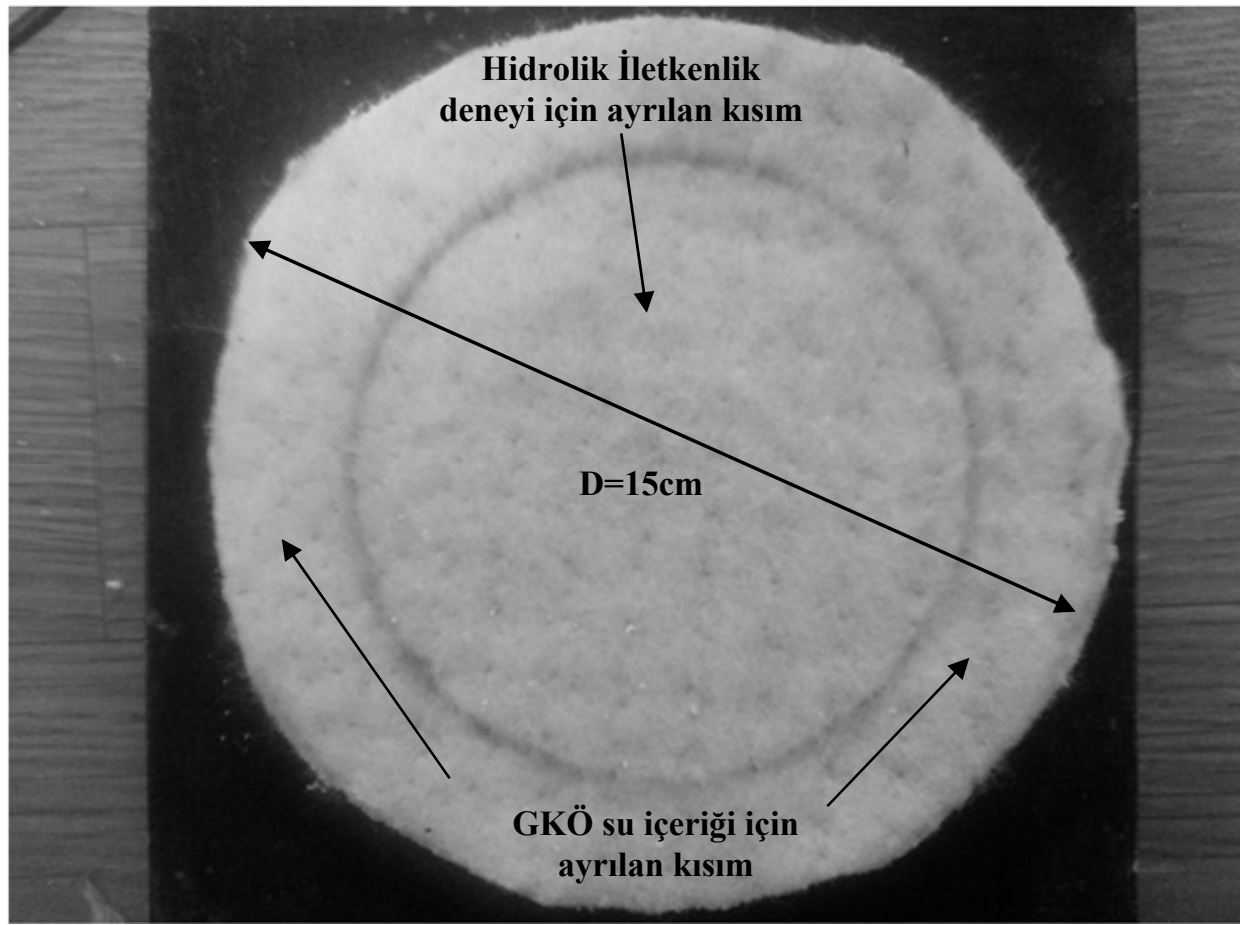

Şekil 4. Tek büyük örnekli yöntemde hidrasyon sonrası hidrolik iletkenlik deneyi ve su içeriği tayini için ayrılan kısımların GKÖ üzerinde gösterilmesi 
Uygulanan kür sürelerinin sonunda alt zemin tabakalarının derinlik boyunca su içerikleri de belirlenmiştir. Bunun için sıkıştırılmış alt zeminler spatula ile $2.5 \mathrm{~cm}$ 'lik tabakalara bölünmüştür. Her iki yöntemde de en altta kalan tabaka kalınlığı örnek boyuna bağlı olarak değişkenlik göstermiştir (son tabaka boyları $11.6 \mathrm{~cm}$ ve $17.4 \mathrm{~cm}$ yüksekliğindeki zeminler için sırasıyla $1.6 \mathrm{~cm}$ ve $2.4 \mathrm{~cm}$ olmuştur). Bölünen tabakaların su içerikleri $105{ }^{\circ} \mathrm{C}$ 'deki etüvde 24 saat boyunca kurutulduktan sonra belirlenmiş ve sonuçlar tabaka ortası su içeriğini temsil edecek şekilde sunulmuştur.

\subsubsection{Hidrolik Illetkenlik Deneyleri}

KÖY ile hidrate edilen diğer GKÖ ve TBÖY ile hidrate edildikten sonra orta kısmından kesilerek çıkarılan GKÖ, hidrolik iletkenlik deneyine tabi tutulmuşlardır. Çalışma boyunca toplam 9 adet hidrolik iletkenlik deneyi yapılmıştır. Deneylerde GKÖ’lerin alt ve üst yüzlerine homojen süzdürme sağlaması için poroz taş yerine Drefon S-1000 tipi geotekstil konmuş ve bu şekilde esnek duvarlı permametre hücresinin alt başlığı üzerine yerleştirilmiştir. Üst başlık da yerleştirildikten sonra kenardan sızmayı önlemek için alt başlık ile üst başlık arasında kalan kenar yüzey Na-bentonit ile sıvanmıştır. Lateks membran geçirilip, O-halkalarda başlıklara tutturulduktan sonra hortum bağlantıları yapılmış ve permametre hücresi kapatılarak içine su doldurulmuştur.

Hidrolik iletkenlik deneyleri ASTM D6766-12 [23] takip edilerek, fakat geri basınç uygulanmadan yapılmıştır. Bu nedenle cam boru (büret) poliüretan hortumla permametre girişine bağlanmış, GKÖ’den süzülen suyu toplamak için permametre çıkış ağzı atmosfere açık şekilde ölçekli mezür içine yerleştirilmiştir. Süzdürme yönü yukarıdan aşağı olacak şekilde permametreye su verilmiştir. Deney boyunca hücre basıncı $35 \mathrm{kPa}$ da sabit tutulmuştur. Büretteki su seviyesine bağlı olarak deneylerde uygulanan ortalama efektif gerilme $27 \mathrm{kPa}$, hidrolik eğim ise 190 hesaplanmıştır. Hidrolik iletkenlik deneyleri 3-6 ay arasında sürdürüldükten sonra tamamlanmıştır.

\section{BULGULAR VE TARTIŞMA}

\subsection{Hidrasyon Yöntemlerinin Alt Zemin Görüntü Oranlarına Bağlı Olarak Karşılaştırılması}

\subsubsection{Aynı Görüntü Oranında Sıkıştırılmış Siltli Kum Tabakaları ile GKÖ Hidrasyonu}

Hidrasyon yöntemlerinin GKÖ su içeriğine etkisi ilk olarak yüksek görüntü oranına sahip sıkıştırılmış alt zemin tabakaları üzerinde denenmiştir. GKÖ’ler, aynı görüntü oranında (GO: 1.14) fakat farklı çap ve boylarda sıkıştırılmış siltli kum tabakaları üzerinde KÖY ile 7, 30 ve 62 gün; TBÖY ile 7 ve 62 gün boyunca hidrate edilmiştir. Hidrasyona maruz bırakılan GKÖ’lerin esnek duvarlı permametre hücreleri içinde yalnızca sıkıştırılmış siltli kum zeminden su emmesi sağlanmıştır. Bu süreler sonunda bentonitlerin sahip olduğu su içerikleri Şekil 5'de hidrasyon yöntemine ve süresine bağlı olarak gösterilmiştir. Genel olarak bakıldığında, her iki yöntemde GKÖ’lerin ilk 7 günde alt zeminden önemli miktarda su emdiği, sonraki süreçte ise bentonit su içeriğinin bir miktar daha artarak hemen hemen sabit bir değere ulaştığı görülmüştür (Şekil 5a). Diğer bir deyişle, başlangıç bentonit su içeriği \%12.6 olan GKÖ’lerin 7 günlük hidrasyon süresi sonunda nihai su içerikleri KÖY'de 
\%56.9'a, TBÖY'de ise \%55.4'e yükselmiş; hidrasyon süresi 62 güne çıkarıldığında ise nihai bentonit su içerikleri bir miktar daha artarak KÖY'de ve TBÖY'de sırası ile \%66.7 ve \%71.7 olarak belirlenmiştir (Şekil 5). Herhangi bir hidrasyon süresi için karşılaştırma yapıldığında (Şekil 5b), 7 günlük hidrasyon sonunda her iki yöntem arasında nihai bentonit su içerikleri açısından pratikte bir fark olmadığı; 62 günlük hidrasyon sonunda ise TBÖY ile elde edilen su içeriğinin KÖY'den elde edilene kıyasla \%8 daha fazla olduğu görülmüştür.
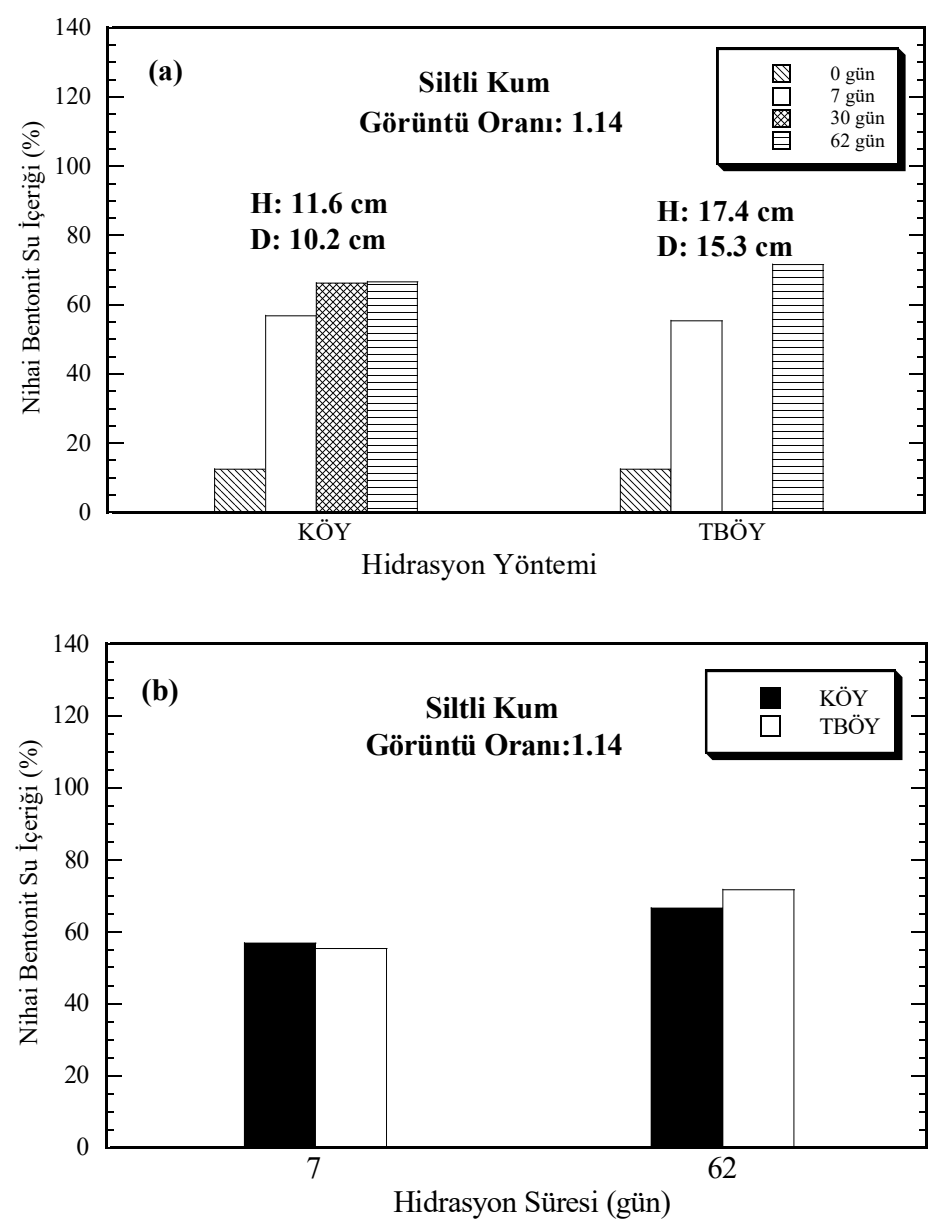

Şekil 5. Aynı görüntü oranında sıkıştırılmış siltli kum üzerinde hidrate edilen GKÖ’lerin nihai bentonit su içeriklerinin: a) hidrasyon süresi ve b) yöntemine bağll olarak karşılaştırılması

Hidrasyon sırasında emme yoluyla su içeriği artan bentonitler, alt zemin tabakalarının su içeriklerinde de değişime sebep olmuştur. Bu değişimin belirlenmesi GKÖ’lerin su emme 
davranışının değerlendirilmesi açısından önemlidir. Kullanılan hidrasyon yönteminin sıkıştırılmış siltli kumun su içeriği üzerindeki etkisi 7 günlük kür süresi için Şekil 6'da iki biçimde gösterilmiştir. İlk gösterimde alt zeminin $2.5 \mathrm{~cm}$ 'lik tabakalara bölünmesi suretiyle belirlenen su içerikleri, tabaka ortaları baz alınarak toplam boy için sunulmuştur (Şekil 6a). Fakat bu gösterimde kullanılan yönteme bağlı olarak alt zemin görüntü oranları aynı olmasına rağmen örnek boylarının birbirinden farklı olduğu görülmektedir $(11.6 \mathrm{~cm}$ ve 17.4 $\mathrm{cm})$. Sonuçların bir başka şekilde de kıyaslanabilmesi için su içeriği belirlenen her tabaka yüksekliği, toplam boya bölünmek suretiyle normalize edilmiştir. Böylece Şekil 6b'de gösterilen ikinci grafik hazırlanmıştır.

Şekil 6a ve 6b'den, tabaka boyunca meydana gelen su içeriği değişsim izlerinin her iki yöntemde de birbirine oldukça benzediği görülebilir. Her iki yöntemde de hidrasyon sonrasında GKÖ ile temas eden en üst alt zemin tabakalarındaki su içeriklerinin ani azaldığı ve takip eden tabakalara kıyasla daha az su içeriğine sahip olduğu görülmüştür. Alt zemine göre nispeten daha kuru ve daha ince daneli bentonit partiküllerinden oluşan GKÖ (\%12.6), kapiler kuvvetler etkisiyle siltli kum tabakasından daha fazla su emmiştir. Bunun neticesinde alt zeminin GKÖ ile temas eden üst tabakasında su içeriği azalırken GKÖ’de su içeriği önemli miktarda artmıştır (Şekil 6).

Diğer yanda ise tabaka boyunca TBÖY'den elde edilen su içerikleri, KÖY'den elde edilenlere kıyasla bir miktar daha yüksektir. Bu farkın, TBÖY'de hazırlanan siltli kum zeminin başlangıç su içeriğinin KÖY'de hazırlanan siltli kum zemine göre daha yüksek olması nedeniyle meydana geldiği düşünülmektedir (Şekil 6).
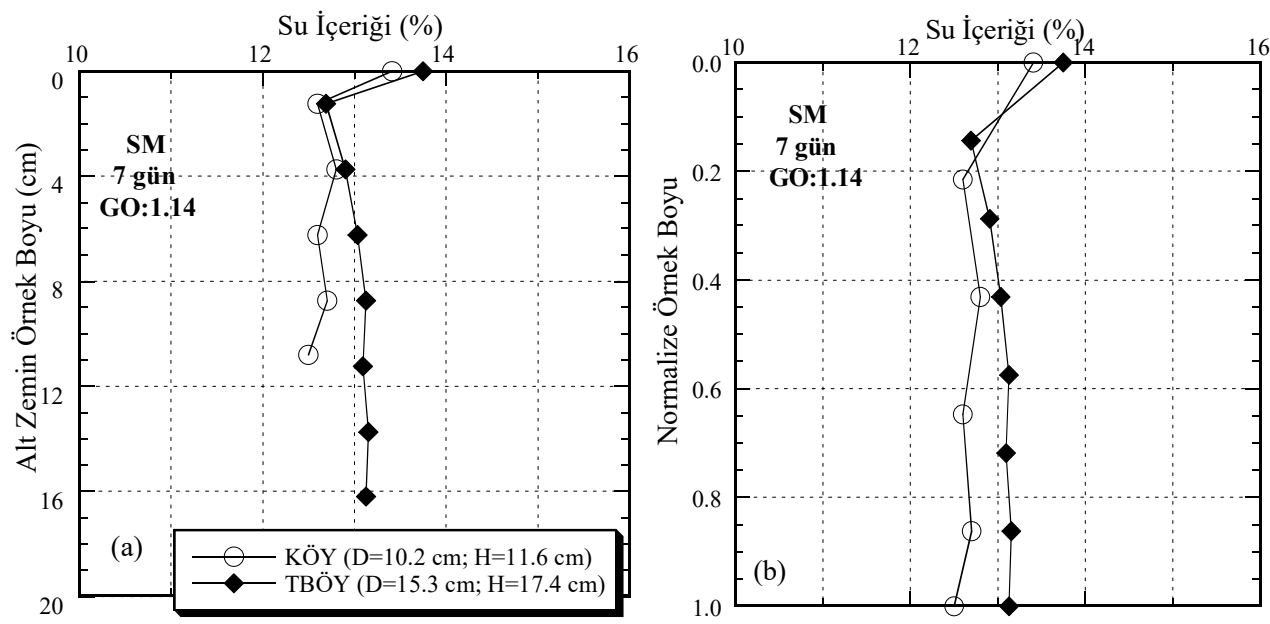

Şekil 6. GKÖ hidrasyon yöntemine bă̆lı olarak 7 gün sonunda sıkıştırılmış siltli kumda: a) orijinal ve b) normalize edilmiş örnek boyunca meydana gelen su içeriği değişimleri

Siltli kumun 62 günlük kür süresi sonundaki su içeriği değişimi örnek boyu ve normalize örnek boyu için Şekil 7a-b'de sunulmuştur. Genel olarak, 62 günlük hidrasyon sonunda elde edilen alt zemin su içeriği profillerinin 7 günlük hidrasyon süresi sonunda elde edilenlere 
oldukça benzediği görülmektedir. Bununla birlikte, 62 gün sonunda TBÖY'den elde edilen siltli kum su içeriklerinin KÖY’e göre daha yüksek olduğu bulgulanmıştır. Bunda, siltli kum başlangıç su içeriğinin TBÖY'de daha fazla olması etkili olmuştur.

Diğer yanda 62 günlük hidrasyon süresi için tabaka bazlı inceleme yapıldığında, kullanılan yönteme bağlı olarak alt zemin su içeriği profilleri arasında bir miktar fark olduğu görülmektedir. KÖY'de en üstteki tabakada su içeriği azaldıktan sonra takip eden tabakada su içeriği artarken, ТВÖY'de ise en üstteki iki tabakada su içeriği azalmış ve daha sonra tekrar artmaya başlamıştır (Şekil 7a). Fakat Şekil 7b'de gösterilen normalize boylar dikkate alındığında, yöntemler arasında sergilenen davranışın birbirine benzer olduğu görülmektedir. Diğer bir deyişle, alt zeminde su içeriği değişimi hemen hemen aynı normalize derinlikte değişmeye başlamıştır. Son tabakalarda ise (örnek taban kısımları) alt zemin su içeriği değerlerinin her iki yöntemde de bir miktar arttığ görülmektedir. Bu durumun yerçekimi etkisi ile belirli bir süre geçtikten sonra suyun alt tabakalara ilerlemesinden kaynaklandığg söylenmektedir [17]. Benzer davranışa, süre kısa olduğu için 7 gün hidrate edilen alt zemin tabakalarında rastlanmamışırır.

Çalışmada uygulanan hidrasyon süreleri dikkate alındığında, her iki yöntemde kullanılan alt zemin tabakası boyutları birbirinden farklı olmasına rağmen görüntü oranı aynı olduğundan tabaka boyunca meydana gelen su içeriği değişimleri de benzer elde edilmiştir (Şekil 6 ve Şekil 7). Aynı şekilde, GKÖ su içerikleri de birbirine oldukça yakın bulgulanmıştır (Şekil $5 a-b)$.
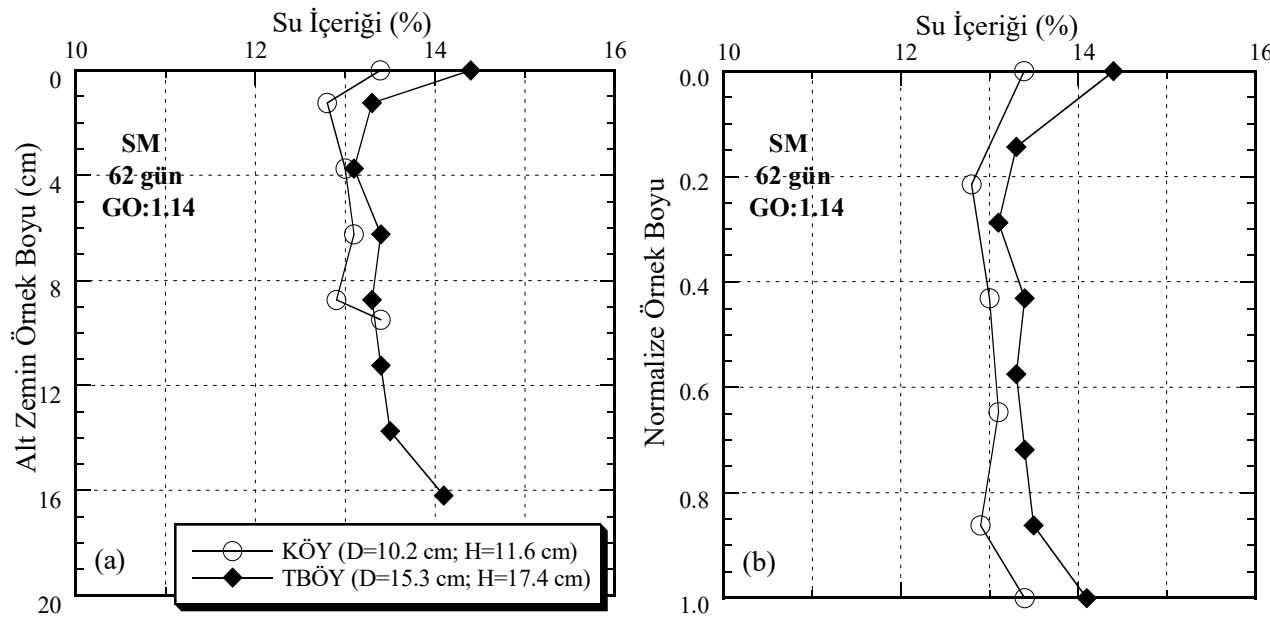

Şekil 7. GKÖ hidrasyon yöntemine bağlı olarak 62 gün sonunda slkıştırılmış siltli kumda: a) orijinal ve b) normalize edilmiş örnek boyunca meydana gelen su içeriği değişimleri 


\subsubsection{Farklı Görüntü Oranında Sıkıştırılmış Siltli Kum Tabakaları ile GKÖ Hidrasyonu}

Aynı görüntü oranına sahip siltli kumun GKÖ hidrasyonu üzerine etkisi belirlendikten sonra yöntem karşılaştırması farklı görüntü oranlarında hazırlanan sıkıştırılmış siltli kum üzerine yerleştirilen GKÖ’ler için incelenmiştir. Bu aşamada siltli kum boyu her iki yöntemde de eşit tutulmuş fakat görüntü oranları değiştirilmiştir (KÖY'de 1.14 ve TBÖY'de 0.76). Diğer bir deyişle, GKÖ’ler aynı boyda $(\mathrm{H}=11.6 \mathrm{~cm})$, fakat farklı çaplarda sıkıştırılan siltli kum tabakaları üzerinde kısa ve uzun dönemi temsilen 7 ve 62 gün boyunca hidrate edilmiştir.

Yeni durumda hidrasyon yöntemlerinin GKÖ davranışına etkisi Şekil 8'de verilmiştir. TBÖY'de görüntü oranının azaltılmasıyla her iki yöntemden elde edilen nihai bentonit su içerikleri arasında kısa dönem hidrasyonda (7 gün) \%7'lik bir fark bulunmuş, ancak hidrasyon süresinin 62 güne çıkarılmasıyla bentonit su içerikleri arasındaki fark \%3'e düşmüştür.

Siltli kumda örnek boyunca elde edilen su içeriği değişimleri daha önce Şekil 6 ve Şekil 7'de verilen davranışlara oldukça benzerlik göstermektedir. Bu nedenle örnek boyunun sabit tutulup, görüntü oranının değiştirildiği durum için alt zemin tabakası su içeriği profillerinin burada tekrar gösterilmesine gerek görülmemiştir.

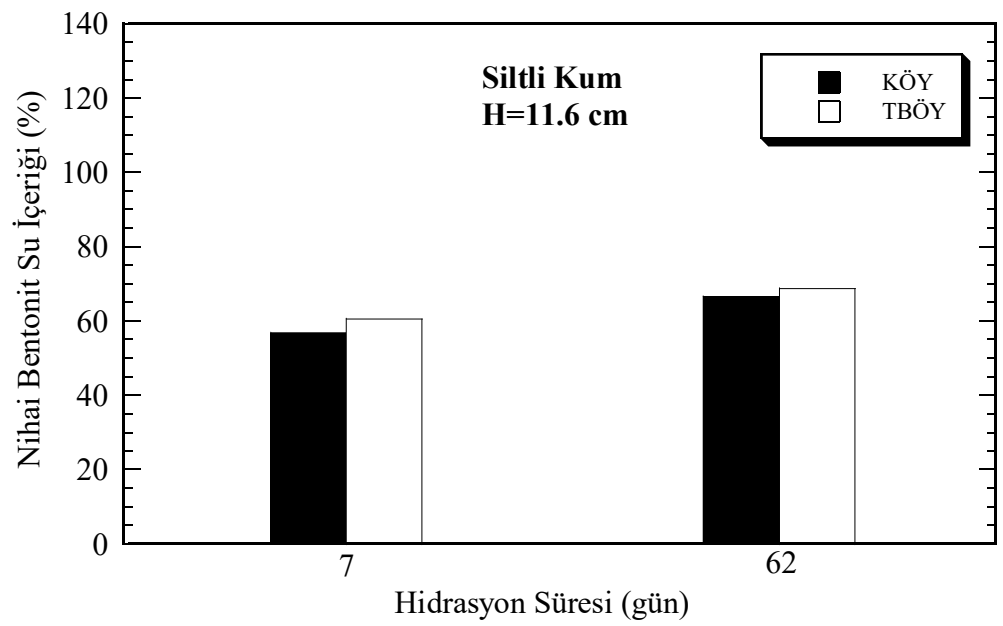

Şekil 8. Farklı görüntü oranında sıkıştırılmış siltli kum üzerinde hidrate edilen GKÖ’lerin nihai bentonit su içeriklerinin hidrasyon yöntemine bağlı olarak karşılaştırılması

\subsubsection{Farklı Görüntü Oranında Sıkıştırılmış Zeolit Tabakaları İle GKÖ Hidrasyonu}

Yöntem karşılaştırması önceki kısımlarda siltli kum zemin için yapılmış olup, bu zemin \%14 su içeriğinde sıkıştırılarak alt zemin tabakaları hazırlanmıştır. Fakat daha yüksek su içeriğine sahip alt zeminlerin kullanılması durumunda yöntem tipine bağlı olarak bentonit su içeriğinde değişism olup olmayacağı belli değildir. Alt zemin tabakası su içeriğinin arttırılmasının GKÖ hidrasyonu üzerinde olumlu etkisinin bulunduğu bilinmektedir. 
Literatürde bu etki killi kum ve siltli kumlar için irdelenmiştir [15, 16, 18]. Ancak bu tip zeminlerin daha yüksek su içeriği değerlerinde sıkıştırılması pratikte mümkün olamamaktadır. Bu sebeple çalışma kapsamında kil ve siltli kumlara kıyasla daha yüksek optimum su içeriğine sahip olan ve sıkıştırma davranışı sergileyen zeolit [24] ikinci alt zemin tabakası olarak seçilmiş ve yöntem karşılaştırması bu tabakalar üzerinde hidrate edilen GKÖ’ler için de yapılmıştır.

Sıkıştırılmış zeolit kullanılarak hidrasyon yöntemlerinin GKÖ davranışı üzerindeki etkisi yine 1.14 ve 0.76 görüntü oranına sahip numuneler üzerinde incelenmiştir (örnek boyları eşit tutulmuştur). Yapılan deneylerde yoğun permametre kullanımının gerekliliği ve deney programının sıkışıklığ 1 göz önüne alınarak GKÖ’ler sıkıştırılmış zeolit tabakaları üzerinde 17 ve 30 gün boyunca hidrate edilmiştir. Kullanılan hidrasyon yöntemlerinin GKÖ davranışına etkisi Şekil 9'da verilmiştir. Sıkıştırılmış zeolit üzerinde hidrate edilen GKÖ’lerin nihai bentonit su içerikleri 17 günlük kür süresi sonunda KÖY ve TBÖY'de sırasıyla \%113.1 ve \%94.7; 30 günlük kür sonunda ise bir miktar daha artarak KÖY'de 122.8; TBÖY'de 126.1'e çıkmıştır. Elde edilen bentonit su içerikleri sıkıştırılmış siltli kum zemin üzerinde KÖY ve TBÖY ile elde edilen maksimum değerlerden (62 günlük hidrasyon süresi sonunda KÖY'de \%66.7; TBÖY'de \%68.8) oldukça yüksektir. Diğer bir deyişle GKÖ hidrasyonunda alt zemin tabakası olarak sıkıştırılmış zeolitin kullanılmasıyla nihai bentonit su içeriklerinde siltli kuma kıyasla daha kısa bir sürede yaklaşık iki katlık artış gözlenmiştir.

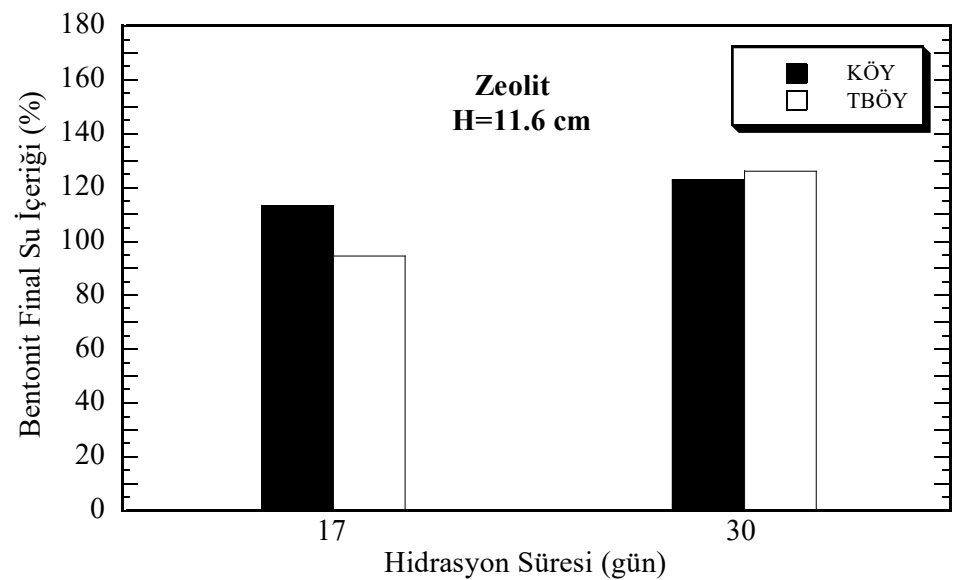

Şekil 9. Farklı görüntü oranında sıkıştırılmış zeolit üzerinde hidrate edilen GKÖ’lerin nihai bentonit su içeriklerinin hidrasyon yöntemine bağlı olarak karşılaştırılması

Aynı ve farklı görüntü oranlarına sahip siltli kum ile GKÖ hidrasyonlarında TBÖY'den elde edilen nihai bentonit su içerikleri KÖY'den elde edilenlerden \%8'e kadar daha yüksek bulgulanmıştır (Şekil 5 ve Şekil 8). Benzer durum 30 gün boyunca sıkıştırılmış zeolit üzerinde hidrate edilen GKÖ’lerde de görülmüştür. Bu süre sonunda TBÖY ile hidrate edilen GKÖ, KÖY'dekine kıyasla \%3 daha fazla nihai bentonit su içeriği değerine ulaşmıştır. Her 
iki yöntem arasındaki fark ne kadar olursa olsun, zeolitin GKÖ hidrasyonuna etkisi siltli kuma göre daha fazladır ve bu durum her iki yöntemle de teyit edilmiştir.

Kullanılan hidrasyon yönteminin alt zemin su içeriği profili üzerindeki etkisi zeolit için de irdelenmiştir (Şekil 10). Şekil 10a'dan da görüleceği gibi 17 günlük hidrasyon süresi sonunda her iki yöntemden elde edilen zeolit su içeriği profilleri siltli kum için elde edilenlerle oldukça benzerlik arz etmektedir. Diğer bir deyişle, GKÖ’ye temas eden en üst zeolit tabakasında su içeriğinde azalma, takip eden tabakada bir miktar artış ve sonrasında stabil değerler bulgulanmıştır (Şekil 10a). Bununla birlikte GKÖ hidrasyonunda TBÖY’ün kullanılması durumunda KÖY'dekine kıyasla daha düşük alt zemin su içeriği değerleri elde edilmiştir. Bu durum sıkıştırılmış zeolitlerin başlangıç su içeriklerinde bir miktar fark olmasından kaynaklanmış olabilir.
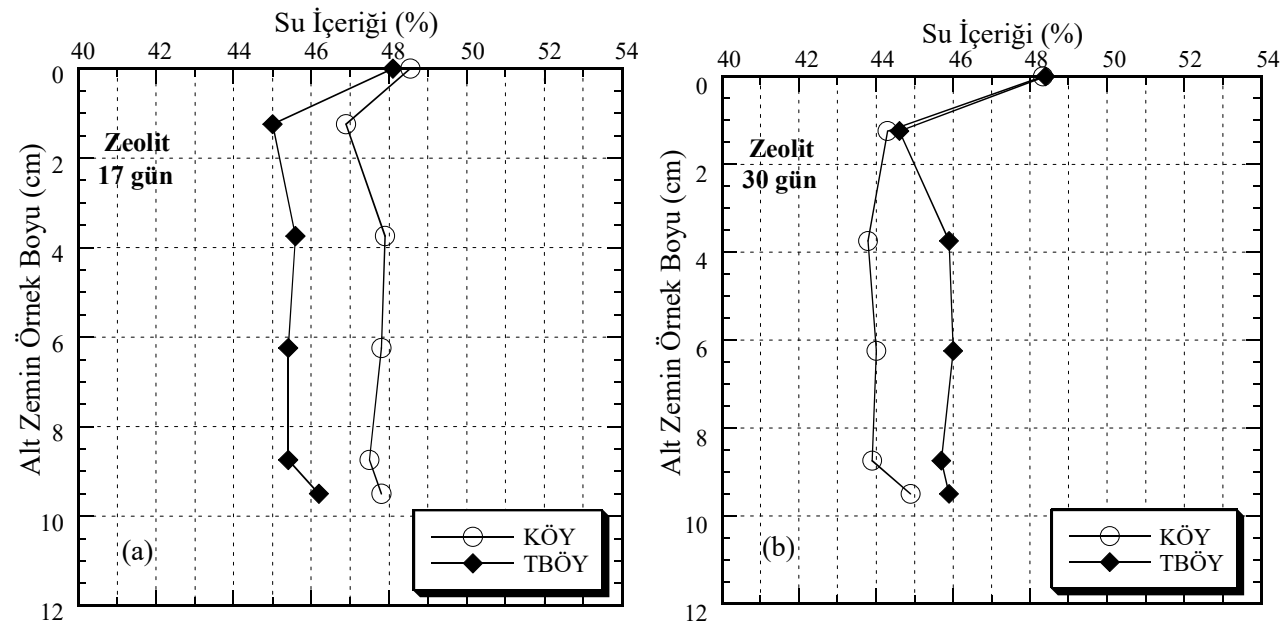

Şekil 10. GKÖ hidrasyon yöntemine bağlı olarak sıkıştırılmış zeolitte meydana gelen su içeriği değişimi: a) 17 gün hidrasyon ve b) 30 gün hidrasyon

Daha uzun hidrasyon süresi dikkate alındığında (30 gün), zeolit boyunca meydana gelen su içeriği değişimleri ise Şekil 10b'de gösterilmiştir. Birbirine oldukça yakın başlangıç su içeriği değerine sahip olan zeolitlerin, GKÖ ile temas eden en üst tabakalarında su içerikleri \%44.5'e düşmüş ve bu tabakadan sonra hidrasyon yöntemine bağlı olarak su içeriği profilleri değişiklik göstermiştir. KÖY'ün kullanılması durumunda en üst tabakayı takip eden tabakada alt zemin su içeriği \%43.8'e düşmüş ve bu değer devam eden tabakalarda yaklaşık olarak sabit kalmıştır. TBÖY'ün kullanıldığ 1 durumda ise ikinci tabakada alt zemin su içeriği artarak \%45.9'a çıkmış ve geri kalan tabakalarda da bu değere oldukça yakın su içerikleri elde edilmiştir.

Zeolit su içeriği profilinde meydana gelen bu fark zeolitlerin başlangıç su içeriklerine bağlı olmayıp (zira birbirine çok yakınlardır), üzerlerine yerleştirilen GKÖ’lerin özelliklerinden kaynaklanmaktadır. Burada GKÖ özelliği, "birim alana düşen bentonit kütlesini” ifade etmek için kullanılmıştır. TBÖY'de yerleştirilen GKÖ'nün birim alana düşen bentonit kütlesi 3.92 
$\mathrm{kg} / \mathrm{m}^{2}$ iken KÖY'de $4.05 \mathrm{~kg} / \mathrm{m}^{2}$ olarak belirlenmiştir. Birim alanda daha düşük miktarda bentonit bulunması, bentonit su içeriğinin artacağı anlamına gelmektedir (su miktarı daha az miktardaki kuru ağırlığa bölünecektir). Gerçekten de TBÖY'den elde edilen nihai bentonit su içerikleri KÖY'den elde edilenlere kıyasla daha fazladır (\%126.1'e karşılık \%122.8).

\subsection{Gözlemsel Yöntem Karşılaştırması}

Her iki yöntemle siltli kum alt zemin tabakası üzerinde 62 gün hidrate edilen GKÖ'lerin durumu gözlemsel incelemeye tabi tutulmuştur. Bunun için hidrasyon süresi tamamlandıktan sonra yukarıda bahsedildiği gibi GKÖ’ler kesilmiş ve bentonit tabakası ortaya çıkarılmıştır.

KÖY ile bentonit partiküllerinin şişerek geçirimsiz bir tabaka oluşturduğu, fakat buna rağmen hala partiküller arasında yer yer boşlukların olduğu görülmektedir. Bu boşlukların dağılımı ve boyutları GKÖ’nün hidrolik iletkenlik davranışını değiştirebileceğinden oldukça önem arz etmektedir (Şekil 11).

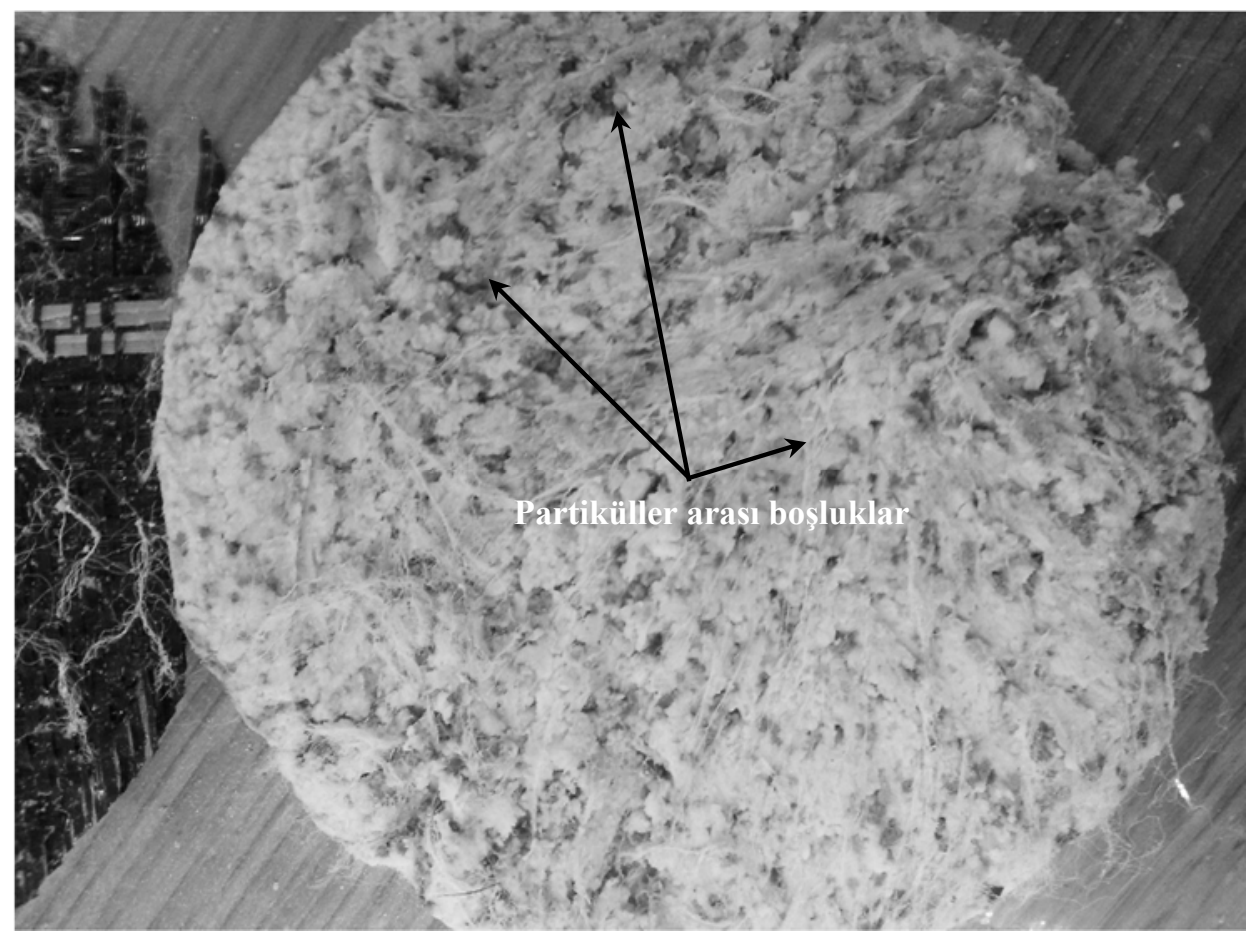

Şekil 11. Siklştırllmış siltli kum üzerinde kontrol örnekli yöntem (KÖY) ile 62 gün hidrasyon sonunda GKÖ'de açığa çıkarılan bentonitin durumu

GKÖ hidrasyonu için uygulanan ikinci yöntemden (TBÖY) elde edilen bentonitin fotoğrafi ise Şekil 12'de gösterilmiştir. GKÖ'nün ortasındaki boşluk, hidrolik iletkenlik deneylerinde 
kullanmak üzere alınan örnekten kaynaklanmaktadır. Şekil 12'de de bentonitlerin şişerek geçirimsiz bir tabaka oluşturduğu görülmektedir. Fakat bu yöntemde tabaka üzerindeki çatlakların KÖY'e göre daha yoğun olduğu gözlenmiştir. GKÖ’den arta kalan kısmın genişliğinin az olması (yaklaşık $2 \mathrm{~cm}$ ) nedeniyle lifler zor kesilmiş; bu durum örneğin örselenmesine ve bentonit tabakası üzerinde doğal olmayan düzlemsel çatlakların oluşmasına sebep olmuştur (Şekil 12). Diğer taraftan TBÖY ile kenarlarda kalan kısmın alanı (Şekil 12), KÖY'deki örneğin alanından (Şekil 11) daha fazladır $\left(98 \mathrm{~cm}^{2}\right.$ 'ye karşılık $\left.79 \mathrm{~cm}^{2}\right)$. Bu alan fazlalığı, su içeriğine ilave olarak bentonitin diğer bazı özelliklerinin belirlenmesi istendiğinde, KÖY'e kıyasla TBÖY'den daha fazla bentonit elde edilebileceği anlamına gelmektedir. Daha fazla bentonit ile bu tip uzun soluklu deneylerden elde edilen bulguların yorumlanmasına yardımcı olacak ilave deneyler yapılabilir (serbest şişme, katyon değişim kapasitesi, yer değiştirebilir katyon miktarı, özgül yüzey alan vb).

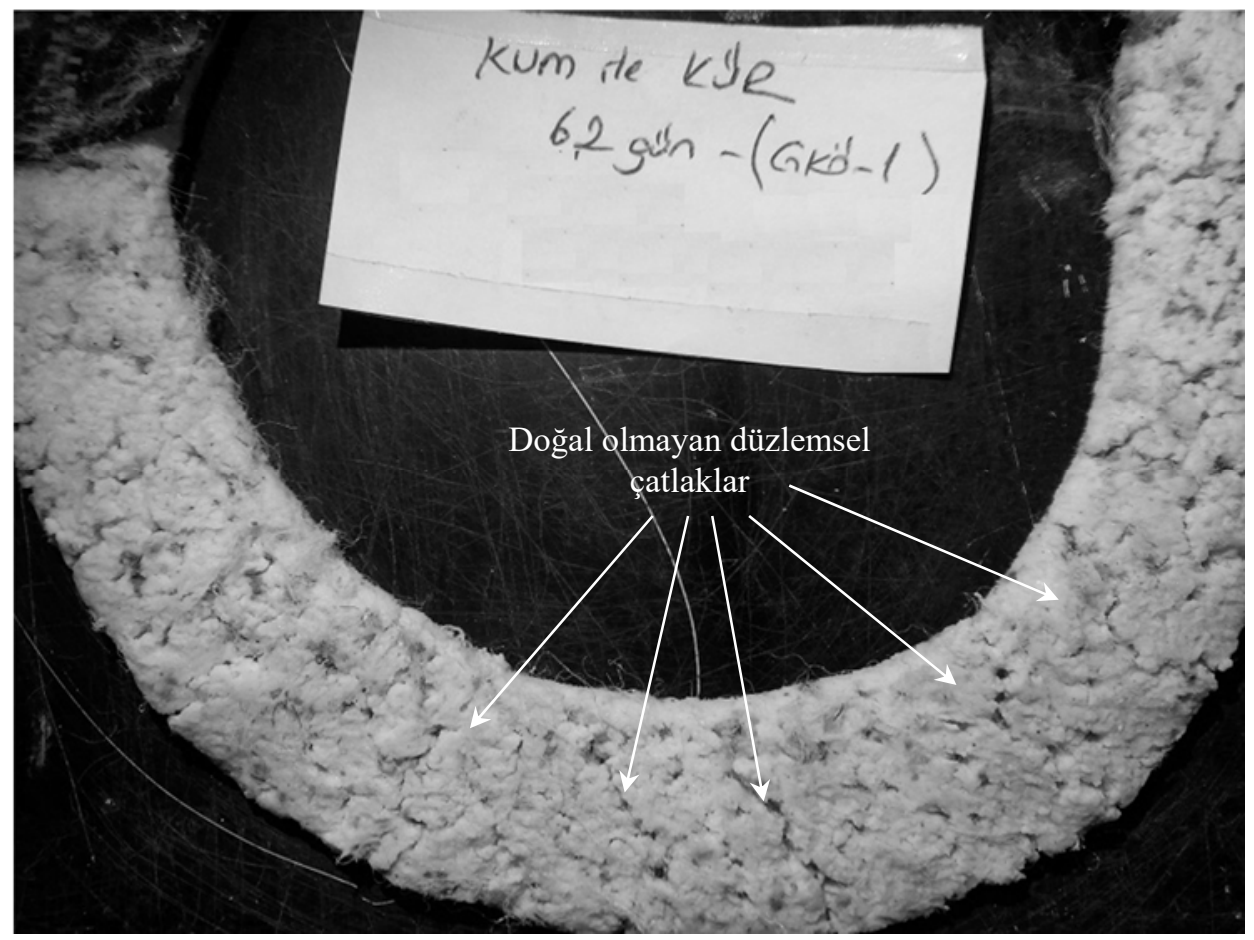

Şekil 12. Sıkıştırılmış siltli kum üzerinde tek büyük örnekli yöntem (TBÖY) ile 62 gün hidrasyon sonunda GKÖ'de açığa çıkarılan bentonitin durumu

\subsection{Hidrolik İletkenlik Deney Sonuçları}

Sıkıştırılmış siltli kum ve zeolit alt zemin tabakaları üzerinde KÖY ve TBÖY ile hidrate edilen GKÖ'lerin nihai hidrolik iletkenlik sonuçları Çizelge 2'de özetlenmiştir. Siltli kum üzerinde hidrate edilen GKÖ'lerin hidrolik iletkenlikleri alt zemin görüntü oranı, deney yöntemi ve hidrasyon süresinden bağımsız olarak $1.7 \times 10^{-9} \mathrm{~cm} / \mathrm{s}$ ile $3.2 \times 10^{-9} \mathrm{~cm} / \mathrm{s}$ arasında 
ölçülmüştür. Aynı vurgu, alt zemin tabakası tipi zeolit olduğunda da geçerli olup, GKÖ’lerin nihai hidrolik iletkenlikleri $1.8 \times 10^{-9} \mathrm{~cm} / \mathrm{s}$ ile $5.7 \times 10^{-9} \mathrm{~cm} / \mathrm{s}$ arasında bulgulanmıştır. $\mathrm{Bu}$ değerler siltli kum tabaka üzerinde hidrate edilen GKÖ'lerin hidrolik iletkenliklerinden bir miktar fazla olsa da bu farkın deneyler arasındaki küçük değişimlerden (efektif gerilme, hidrolik eğim vb) kaynaklanmış olması oldukça muhtemeldir ve bu nedenle pratikte önemsiz kabul edilebilir.

Çizelge 2. Farkll alt zemin tabakalarl, kür süreleri ve deney yöntemi ile hidrate edilen GKÖ'lerin hidrolik iletkenlik sonuçları

\begin{tabular}{ccccccc}
\hline $\begin{array}{c}\text { Deney } \\
\text { No }\end{array}$ & $\begin{array}{c}\text { Alt Zemin } \\
\text { Tabakası } \\
\text { Tipi }\end{array}$ & $\begin{array}{c}\text { Alt Zemin } \\
\text { Örnek } \\
\text { Boyu (cm) }\end{array}$ & $\begin{array}{c}\text { Alt } \\
\text { Zemin } \\
\text { Görüntü } \\
\text { Oranı }\end{array}$ & $\begin{array}{c}\text { Deney } \\
\text { Yöntemi }\end{array}$ & $\begin{array}{c}\text { Hidrasyon } \\
\text { Süresi } \\
\text { (gün) }\end{array}$ & $\begin{array}{c}\text { Hidrolik } \\
\text { Iletkenlik } \\
\text { (cm/s) }\end{array}$ \\
\hline $\mathbf{1}$ & Siltli Kum & 11.6 & 1.14 & KÖY & 7 & $2.3 \times 10^{-9}$ \\
$\mathbf{2}$ & Siltli Kum & 17.4 & 1.14 & TBÖY & 7 & $1.7 \times 10^{-9}$ \\
$\mathbf{3}$ & Siltli Kum & 11.6 & 0.76 & TBÖY & 7 & $3.2 \times 10^{-9}$ \\
$\mathbf{4}$ & Siltli Kum & 11.6 & 1.14 & KÖY & 62 & $2.6 \times 10^{-9}$ \\
$\mathbf{5}$ & Siltli Kum & 17.4 & 1.14 & TBÖY & 62 & $1.7 \times 10^{-9}$ \\
$\mathbf{6}$ & Zeolit & 11.6 & 1.14 & KÖY & 17 & $1.8 \times 10^{-9}$ \\
$\mathbf{7}$ & Zeolit & 11.6 & 0.76 & TBÖY & 17 & $5.7 \times 10^{-9}$ \\
$\mathbf{8}$ & Zeolit & 11.6 & 1.14 & KÖY & 30 & $4.1 \times 10^{-9}$ \\
$\mathbf{9}$ & Zeolit & 11.6 & 0.76 & TBÖY & 30 & $2.5 \times 10^{-9}$ \\
\hline
\end{tabular}

GKÖ’lerin nihai hidrolik iletkenlikleri birbirine yakın elde edilmiş olsa da hidrolik iletkenlik davranışları arasında önemli farklar elde edilmiştir. Çizelge 2'de verilen hidrolik iletkenlik deneylerinin tümünde başlangıç geçirgenlik değerleri yaklaşı $2.0 \times 10^{-6} \mathrm{~cm} / \mathrm{s}$ elde edilmiştir. Daha sonra GKÖ’lerden belirli bir "boşluk hacmi cinsinden akış miktarı (BHCAM)" kadar su geçişi gerçekleştiğinde hidrolik iletkenlikler azalmaya başlamış ve ortalama $2.8 \times 10^{-9} \mathrm{~cm} / \mathrm{s}$ seviyelerine kadar inmiştir (Şekil 13). Fakat Şekil 13'te gösterilen hidrolik iletkenlik davranışı deney yönteminden bağımsız olarak elde edilmiştir. Diğer bir deyişle, uygulanan deney yönteminin GKÖ’lerin hidrolik iletkenlik davranışlarında bir etkisi yoktur.

Hidrolik iletkenlik davranışındaki değişimler, hidrasyon yöntemi veya alt zemin görüntü oranından ziyade hidrasyon süresinden ve dolayısıyla bentonitlerin su içerikleri arasındaki farktan kaynaklanmaktadır. Hidrasyon sonunda bentonitlerin sahip olduğu su içeriği değerleri düşük olduğu için hidrolik iletkenlik deneyleri sırasında bentonitler bünyelerine su alarak şişmeye devam etmiştir. Hidrasyondan sonra yapılan işleme benzer şekilde hidrolik iletkenlik deneyi tamamlandığında, GKÖ'lerin iğnelenmiş lifleri keskin uçlu maket bıçağıyla kesilmiş ve geotekstiller arasındaki bentonit açığa çıkarılmıştır (Şekil 14). Daha sonra bu 
bentonitler, Şekil 11 ve Şekil 12'de verilen hidrasyon sonrasındaki bentonitlerin durumu ile karşılaştırılmıştır.

Hidrasyondan sonra bentonit partüküllerinin topaklar oluşturduğu ve topaklar arasında yer yer boşlukların olduğu görülürken (Şekil 11 ve Şekil 12), hidrolik iletkenlik deneyi sırasında bentonitlerin şişmesiyle GKÖ içinde daha homojen yer kaplayan partiküllerin topaklar arasındaki boşlukları kapattığı gözlenmiştir (Şekil 14). Bu bulgu su içeriği sonuçlarıyla da desteklenmektedir. Sıkıştırılmış siltli kum ve zeolit tabakaları üzerinde hidrate edilen GKÖ’lerin nihai su içerikleri sırasıyla \%72 ve \%126 iken hidrolik iletkenlik deneyi tamamlandığında bu değerler sırasıyla \%186 ve \%152'ye yükselmiştir.

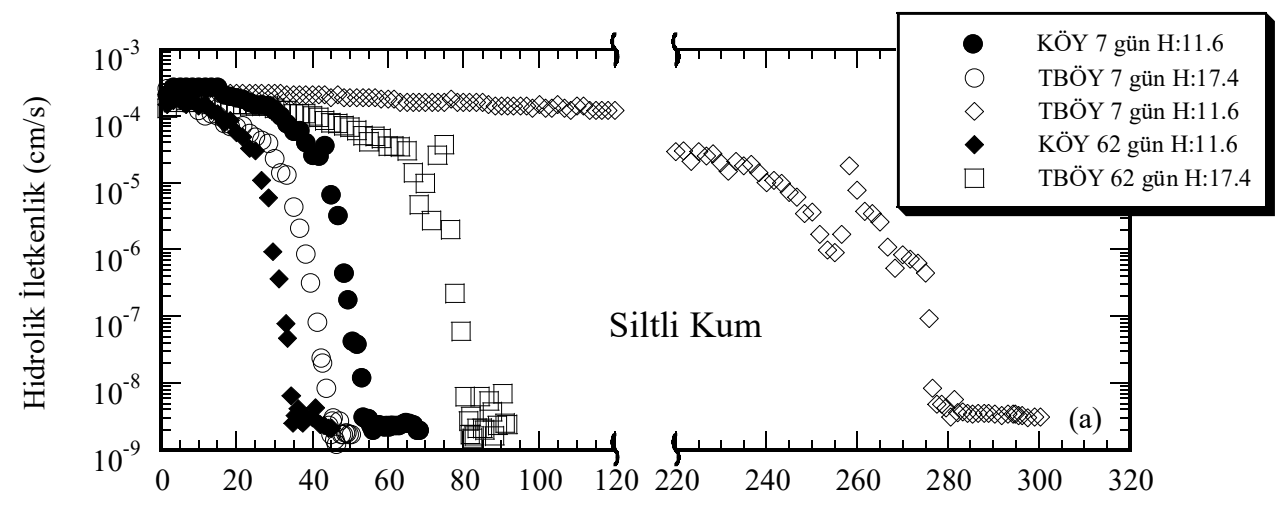

Boşluk Hacmi Cinsinden Akış Miktarı

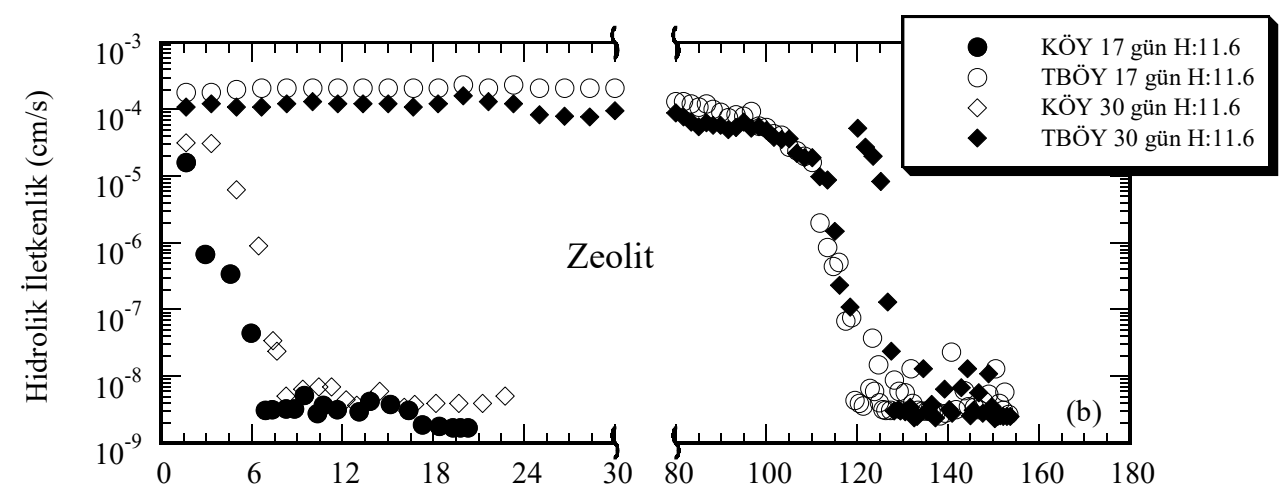

Boşluk Hacmi Cinsinden Akış Miktarı

Şekil 13. Sıkıştırılmış alt zemin tabakaları üzerinde hidrate edilen GKÖ’lerin hidrolik iletkenlik davranısları: a) Siltli kum ve b) zeolit üzerinde hidrasyon 

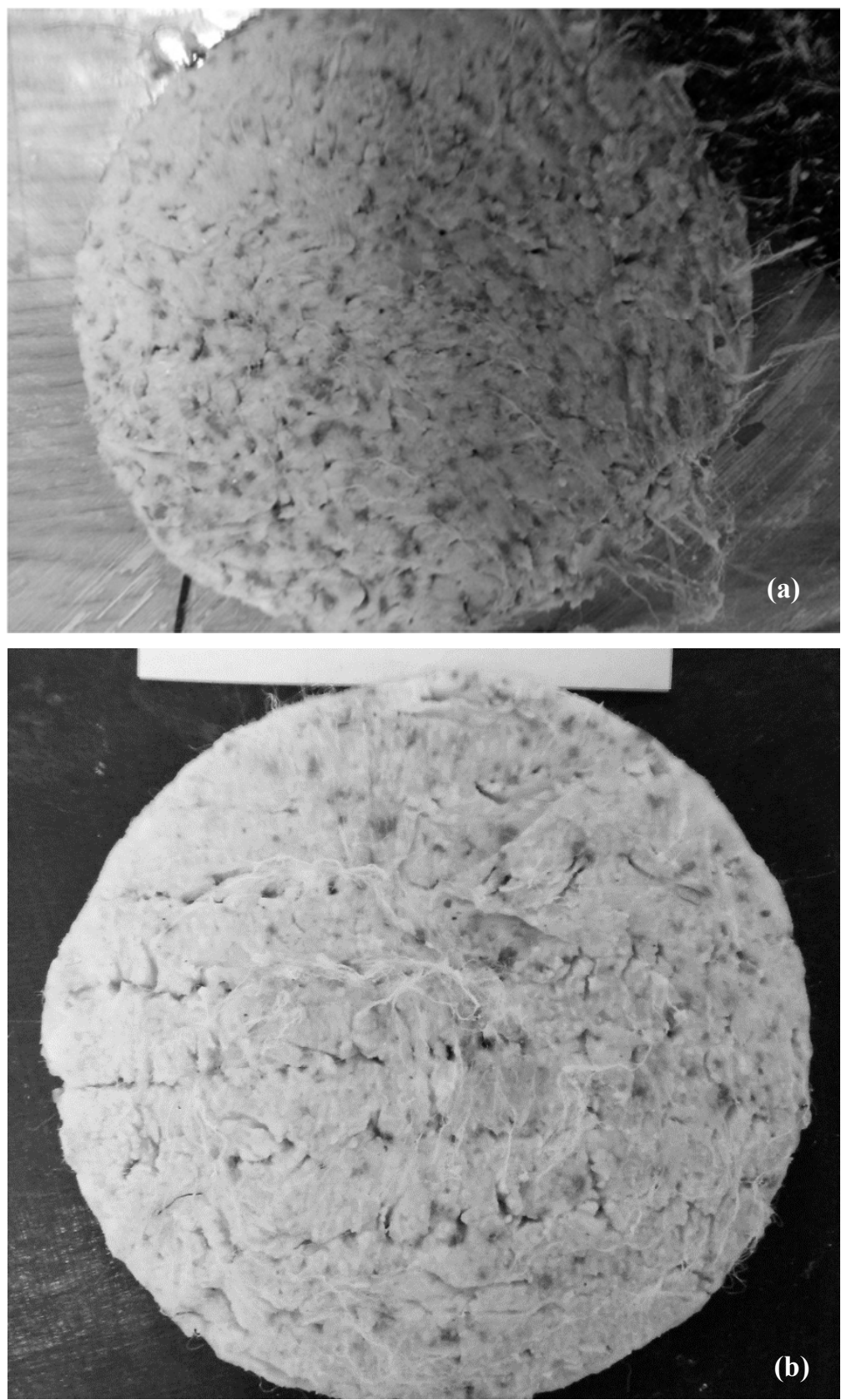

Şekil 14. Siklştırllmış siltti kum üzerinde 62 gün hidrasyon sonunda GKÖ'de açı̆̆a çıkarılan bentonitin durumu: a) kontrol örnekli yöntem (KÖY) ve b) tek büyük örnekli yöntem (TBÖY) 


\section{SONUÇLAR}

Bu çalışmada GKÖ hidrasyonunda esnek duvarlı permametre hücrelerinin kullanıldığı iki yöntem karşılaştırılmıştır. Yöntem karşılaştırması görüntü oranı ve alt zemin tipine bağlı olarak deney bulguları ve gözlemlerle desteklenmiştir.

GKÖ hidrasyon çalışması alt zemin tabakası olarak siltli kumun kullanıldığı durumda aynı ve farklı görüntü oranlarında sıkıştırılan örnekler için incelenmiştir. Aynı görüntü oranına (GO:1.14) sahip örneklerde TBÖY'den elde edilen nihai bentonit su içeriği KÖY ile elde edilene kıyasla \%8 daha yüksektir. Örnek boyu sabit tutularak farklı görüntü oranlarında (KÖY için GO:1.14, TBÖY için GO:0.76) hazırlanan siltli kumlar üzerinde hidrate edilen GKÖ’lerde de TBÖY'de KÖY'e kıyasla \%7'ye kadar daha yüksek nihai bentonit su içerikleri elde edilmiştir.

Farklı görüntü oranlarında sıkıştırılan ve siltli kuma kıyasla daha yüksek sıkıştırma su içeriğine sahip zeolitin alt zemin olarak kullanıldığı durumda, 30 gün sonunda her iki yöntemde de nihai bentonit su içerikleri yaklaşı \% $\% 125$ seviyesine çıkmıştır (siltli kumda 62 gün sonunda bu değer \%65-70 civarındadır).

Alt zemin tabakası olarak siltli kum ve zeolit kullanıldığında, tabaka yüksekliği boyunca birbirine benzer su içeriği profilleri elde edilmiştir. Diğer bir deyişle GKÖ’ye temas eden en üstteki tabakada su içerikleri ani azalmış ve takip eden tabakalarda artış göstermiştir. Örneğin alt kısımlarına doğru su içeriklerinde görülen artış ise yer çekimi kuvvetiyle kür süresi içerisinde boşluk suyunun aşağıya doğru hareket etmesine atfedilmiştir.

Gözlemsel incelemede, kontrol örnekli yöntem (KÖY) ile bentonitin şişmesi daha iyi resmedilmiştir. Bu yöntemde partiküller arasındaki boşluklar net bir şekilde görülürken, tek büyük örnekli yöntem (TBÖY)'de kesim sırasında yaşanılan güçlükten dolayı GKÖ bir miktar örselenmiştir. Bentonitin şişmesi bu yöntemde de görülmüş, fakat kesim sırasında doğal olmayan çatlakların oluşmasına engel olunamamıştır.

GKÖ’lerin nihai hidrolik iletkenliklerinde hidrasyon süresi, alt zemin tipi, deney yöntemi gibi faktörlerin etkisi görülmemiştir. Her iki yöntemle farklı alt zeminlerde hidrate edilen GKÖ’lerin hidrolik iletkenlikleri ortalama $2.8 \times 10^{-9} \mathrm{~cm} / \mathrm{s}$ ölçülmüştür.

GKÖ’lerin nihai hidrolik iletkenlikleri birbirine yakın olmasına rağmen, hidrolik iletkenlik davranışları farklıdır. Bu farklılıkta hidrasyon sonu bentonit su içeriğinin hidrolik iletkenlik deneyi sırasında daha da artma eğiliminde olması etken olmuştur. Bentonitlerin su içeriklerinin zaman içinde yavaşça artması, hidrolik iletkenlikte de kademeli azalmaya sebep olmuştur. Bu bulgu, bentonitlerin deney sonrasındaki görüntülerinin karşılaştırılmasıyla da teyit edilmiştir.

Yukarıda elde edilenler 1şı̆̆ında her iki yöntemden elde edilen nihai bentonit su içerikleri arasındaki fark pratikte önemsiz kabul edilebilir. Fakat KÖY ve TBÖY'ün birbirine göre avantajları ve dezavantajları bulunmaktadır. TBÖY, tek permametrenin kullanılması açısından avantaj teşkil etmekte ve tek örnekten su içeriği ve hidrolik iletkenlik deneyi için numune alınmasına müsaade etmektedir. Ayrıca, bu yöntemde hidrolik iletkenlik numunesi çıkarıldıktan sonra GKÖ üzerinde arta kalan yüzey alanı KÖY'den elde edilen alana göre yaklaşık \%25 daha fazladır. Alandaki bu fark TBÖY'den daha fazla bentonit temin edilebileceği anlamına gelmektedir. Böylece su içeriğine ilave olarak bentonitin fiziko 
kimyasal özelliklerinden bazıları da belirlenebilir. KÖY'de ise şişmiş bentonitler daha iyi görüntülenmesine rağmen, aynı anda iki permametre kullanıldığından yöntem pahalı ve zahmetli olmaktadır.

\section{Teşekkür}

Bu çalışma kapsamında kullanılan permametre hücreleri 111M718 nolu projeden alınmıştır. TÜBİTAK'a projeye verdiği bu maddi destek için teşekkür ederiz.

\section{Semboller}

$\begin{array}{ll}\text { AR } & \text { : Aspect Ratio } \\ \text { CSM } & \text { : Control Sample Method } \\ \text { GCL } & \text { : Geosynthetic Clay Liner } \\ \text { SLSM } & \text { : Single Large Sample Method } \\ \text { D } & \text { : Örnek çapı } \\ \text { L } & \text { : Örnek boyu } \\ \text { GO } & \text { : Görüntü Oranı } \\ \text { GKÖ } & \text { : Geosentetik Kil Örtü } \\ \text { KÖY } & : \text { Kontrol Örnekli Yöntem } \\ \text { TBÖY } & : \text { Tek Büyük Örnekli Yöntem } \\ \text { w } & : \text { bentonit su içeriği }\end{array}$

\section{Kaynaklar}

[1] Bouazza, A., Geosynthetic Clay Liners, Geotextiles and Geomembranes, 20, 3-17, 2002.

[2] Katsumi, T., Ishimori, H., Onikata, M., Fukagawa, R., Long term Barrier Performance of modified bentonite materials Against Sodium and Calcium Permeant Solutions, Geotextiles and Geomembranes, 26, 14-30, 2008.

[3] Lee, J-M., Shackelford, C.D., Impact of Bentonite Quality on Hydraulic Conductivity of Geosynthetic Clay Liners, Journal of Geotechnical and Geoenvironmental Engineering, 131 (1): 64-77, 2005.

[4] Shan, H.Y., Lai, Y.J., Effect of Hydrating Liquid on the Hydraulic Properties of Geosynthetic Clay Liners, Geotextiles and Geomembranes, 20 : 19-38, 2002.

[5] Jo, H. Y., Benson, C. H., Shackelford, C. D., Lee, J. M., Edil, T. B., Long-term Hydraulic Conductivity of a Geosynthetic Clay Liner Permeated with Inorganic Salt Solutions, Journal of Geotechnical and Geoenvironmental Engineering, 131 (4), 405417, 2005. 
[6] Jo, H. Y., Katsumi, T., Benson, C. H., Edil, T. B., Hydraulic Conductivity and Swelling of Nonprehydrated GCLs Permeated with Single-species Salt Solutions, Journal of Geotechnical and Geoenvironmental Engineering, 127 (7), 557-567, 2001.

[7] Benson, C.H., Ören, A.H, Gates, W.P., Hydraulic Conductivity of Two Geosynthetic Clay Liners Permeated with a Hyperalkaline Solution." Geotextiles and Geomembranes, 28(2), 206-218, 2010.

[8] Ören, A. H., Demirkıran H., Geosentetik Kil Örtülerin Hidrolik İletkenliklerinin Laboratuvarda Belirlenmesi Üzerine Bir Çalışma, IMO Teknik Dergi, 26(4), 71917213, 2015.

[9] Meer, S.R., Benson, C.H., Hydraulic Conductivity of Geosynthetic Clay Liners Exhumed From Landfill Final Covers, Journal of Geotechnical and Geoenvironmental Engineering, 133 (5), 550-563, 2007.

[10] Scalia, J., Benson, C.H., Preferential Flow in Geosynthetic Clay Liners Exhumed from Final Covers with Composite Barriers, Canadian Geotechnical Journal, 47: 1101-1111, 2011.

[11] Benson, C.H., Thorstad, P.A., Jo, H.Y., Rock S.A., Hydraulic Performance of Geosynthetic Clay Liners in a Landfill Final Cover, Journal of Geotechnical and Geoenvironmental Engineering, 133 (7), 814-827, 2007.

[12] Estornell, P., Daniel, D., Hydraulic Conductivity of Three Geosynthetic Clay Liners, Journal of Geotechnical Engineering, 118(10), 1592-1606, 1992.

[13] Petrov, R. J., Rowe, R. K., Quigley, R. M., Selected Factors Influencing GCL Hydraulic Conductivity, Journal of Geotechnical and Geoenvironmental Engineering, 123(8), 683-695, 1997.

[14] Rayhani, M.T., Rowe, R.K., Brachman, R.W., Take, W.A., Siemens, G., Factors Affecting GCL Hydration Under Isothermal Conditions, Geotextiles and Geomembranes, 29 (6): 525-533, 2011.

[15] Anderson, R., Rayhani, M. T., Rowe, R. K., Laboratory Investigation of GCL Hydration from Clayey Sand Subsoils, Geotextiles and Geomembranes, 31, 31-38, 2012.

[16] Sarabian, T., Rayhani, M.T., Hydration of Geosynthetic Clay Liners from Clay Subsoil Under Simulated Field Conditions, Waste Management, 33 (1): 67-73, 2013.

[17] Barclay, A., Rayhani M.T., Effect of Temperature on Hydration of Geosynthetic Clay Liners in Landfills, Waste Management \& Research, 31 (3), 265-72, 2013.

[18] Chevrier, B., Cazaux, D., Didier, G., Gamet, M., Guyonnet, D., Influence of Subgrade, Temperature and Confining Pressure on GCL Hydration, Geotextiles and Geomembranes, 33, 1-6, 2012.

[19] Katsumi, T., Ishimori, H., Ogawa, A., Maruyama, S., Fukagawa, R., Effects of Water Content Distribution on Hydraulic Conductivity of Prehydrated GCLs Against Calcium Chloride Solutions, Soils and Foundations, 48 (3), 407-417, 2008. 
[20] Bradshaw, S.L., Benson, C.H., Effect of Municipal Solid Waste Leachate on Hydraulic Conductivity and Exchange Complex of Geosynthetic Clay Liners, Journal of Geotechnical and Geoenvironmental Engineering, 140 (4): 04013038, 2013.

[21] ASTM D698-07, Standard Test Methods for Laboratory Compaction Characteristics of Soil Using Standard Effort $(12,400 \mathrm{ft}-1 \mathrm{bf} / \mathrm{ft} 3(600 \mathrm{kN}-\mathrm{m} / \mathrm{m} 3))$, American Society for Testing and Materials, ASTM International, West Conshohocken, Pa, 2012.

[22] Ören A.H., Demirkıran H., Geosentetik Kil Örtülerin Hidrolik İletkenliklerinin Laboratuvarda Belirlenmesi Üzerine Bir Çalışma.” İMO Teknik Dergi, 26 (129), 7191$7213,2015$.

[23] ASTM D6766-12, Standard Test Method for Evaluation of Hydraulic Properties of Geosynthetic Clay Liners Permeated with Potentially Incompatible Aqueous Solutions, American Society for Testing and Materials, ASTM International, West Conshohocken, Pa, 2012.

[24] Ören A.H., Özdamar T., Hydraulic Conductivity of Compacted Zeolites, Waste Management and Research, 31, 634-640, 2013. 
